\title{
Metabolic Versatility of Mycobacterium tuberculosis during Infection and Dormancy
}

\author{
Dorothy Pei Shan Chang (D) and Xue Li Guan* \\ Lee Kong Chian School of Medicine, Nanyang Technological University, 59 Nanyang Drive, \\ Singapore 636921, Singapore; PEISHAND001@e.ntu.edu.sg \\ * Correspondence: xueli.guan@ntu.edu.sg
}

check for updates

Citation: Chang, D.P.S.; Guan, X.L. Metabolic Versatility of Mycobacterium tuberculosis during Infection and Dormancy. Metabolites 2021, 11, 88. https://doi.org/10.3390/metabo11020088

Academic Editor: Robert A. Quinn Received: 19 December 2020

Accepted: 29 January 2021

Published: 2 February 2021

Publisher's Note: MDPI stays neutral with regard to jurisdictional claims in published maps and institutional affiliations.

Copyright: (c) 2021 by the authors. Licensee MDPI, Basel, Switzerland. This article is an open access article distributed under the terms and conditions of the Creative Commons Attribution (CC BY) license (https:/ / creativecommons.org/licenses/by/ $4.0 /)$.

\begin{abstract}
Mycobacterium tuberculosis (Mtb), the causative agent of tuberculosis (TB), is a highly successful intracellular pathogen with the ability to withstand harsh conditions and reside long-term within its host. In the dormant and persistent states, the bacterium tunes its metabolism and is able to resist the actions of antibiotics. One of the main strategies $M t b$ adopts is through its metabolic versatility - it is able to cometabolize a variety of essential nutrients and direct these nutrients simultaneously to multiple metabolic pathways to facilitate the infection of the host. Mtb further undergo extensive remodeling of its metabolic pathways in response to stress and dormancy. In recent years, advancement in systems biology and its applications have contributed substantially to a more coherent view on the intricate metabolic networks of $M t b$. With a more refined appreciation of the roles of metabolism in mycobacterial infection and drug resistance, and the success of drugs targeting metabolism, there is growing interest in further development of anti-TB therapies that target metabolism, including lipid metabolism and oxidative phosphorylation. Here, we will review current knowledge revolving around the versatility of $M t b$ in remodeling its metabolism during infection and dormancy, with a focus on central carbon metabolism and lipid metabolism.
\end{abstract}

Keywords: metabolism; Mycobacterium tuberculosis; tuberculosis; infection; dormancy; systems biology

\section{Introduction}

Despite the availability of treatment, Mycobacterium tuberculosis $(M t b)$, the causative agent of tuberculosis (TB), remains a highly successful pathogen circulating globally, with almost 10 million new cases and 1.2 million deaths per year [1]. There is a resurgence of TB cases and the spread of multidrug resistant (MDR) TB. The secret to $M t b^{\prime}$ 's success lies in its ability to evade host immune defenses and anti-TB drugs [2], and to persist in the absence of growth. Mtb exhibits metabolic flexibility, contributing to its long-term persistence and its ability to cause latent TB in a staggering one-fourth of the human population [3]. These individuals are reservoirs of carriers as the dormant bacterium can potentially reactivate, leading to manifestation of active TB. The patient will develop symptoms including persistent cough and can spread the disease through airborne particles containing $M t b$.

As $M t b$ navigates through the human host system to establish an infection, it needs to withstand and adapt to various harsh environments, such as varying acidity, osmolarity and nutrient-deficient microenvironment. The metabolic versatility of the tubercle bacilli plays a critical role in its survival and persistence in limiting conditions within the host. As a heterotroph, $M t b$ is capable of metabolizing multiple carbon sources, which can be synthesized by the bacterium or acquired from the host cells [4-7]. The bacterium is further able to switch between replicative and non-replicative states, through rerouting of its metabolic networks, in response to the varying host environments. Dormancy refers to the reversible non-replicative state in which the tubercle bacilli are viable but exhibit low or minimal metabolic activity (reviewed in [8-11]). This regulated phenomenon is 
induced when the bacilli are subjected to unfavorable growth conditions, including nutrient limitation or low oxygen. Once returned to favorable conditions, the metabolic rate of $M t b$ reverts to normal, and growth of the bacilli is reactivated, which can lead to establishment of active infection. Dormant $M t b$, due to its low or minimal metabolic rate, is able to evade the actions of anti-TB drugs, which target actively growing bacterium. Phenotypic resistance is also observed in another subpopulation of bacilli, known as persisters (reviewed in [12]). These bacilli have consistently low metabolic rates even under optimal growth conditions. The ability of dormant and persister subpopulations of $M t b$ to survive under antibiotic exposure is a major concern in anti-TB treatment as they are difficult to eradicate and further serves as a pool of bacterium, which over a long period of antibiotics exposure can potentially acquire genetic mutations of resistance.

The metabolic capability and versatility of $M t b$ has clearly contributed to its success as a pathogen during establishment of infection and its persistence (reviewed in [13]). Moreover, the susceptibility of $M t b$, and other pathogens, to antibiotics treatment is clearly dependent on their metabolic states [14]. Indeed, with the renewed appreciation of the critical roles of metabolism in $M t b$ survival during infection and dormancy, development of drugs targeting mycobacterial metabolism is an obvious potential anti-TB strategy. Numerous studies using classical genetics and biochemistry of specific key enzymes have led to the understanding of the relevance of mycobacterial metabolism during infection and dormancy. Since metabolism is an intricate process that involves a vast network of enzymes and metabolites, the emergence of system biology approaches has in recent years allowed us to piece the metabolic jigsaw puzzle together and contributed to a more comprehensive view of the metabolism of mycobacteria.

This review aims to discuss the current knowledge revolving around the versatility of $M t b$ in remodeling its metabolism during (1) infection and (2) stress and dormancy, with a focus on central carbon metabolism and lipid metabolism. We will discuss instances of novel drugs that target mycobacterial metabolism, but this is not exhaustive, and readers are referred to more extensive reviews available [15-17]. Finally, we will present how recent applications of systems biology approaches have contributed to a more coherent view of the metabolic responses of $M t b$.

\section{Mycobacterium and Its Metabolic Versatility during Infection}

During the process of infection, $M t b$ transits between airborne droplets, mucosal epithelia, alveolar macrophages, necrotic cells and caseous granulomas [18]. The plasticity of its metabolism enables $M t b$ to adapt to the varying environments that it colonizes. Metabolism of carbon sources plays a large role during infection by $M t b$. In bacteria, there are two types of growth behavior: diauxic and coutilization of carbon sources. In diauxic growth, the bacterium metabolizes the carbon source that supports the fastest growth. When this carbon source is depleted, the bacterium subsequently metabolizes the next preferred carbon source with the involvement of carbon catabolite repression [19]. $M t b$ on the other hand has a preference for coutilization of carbon sources during its growth [5]. Specifically, it catabolizes multiple carbon sources simultaneously via compartmentalization of discrete metabolic process both in vitro [5] and in macrophages [6,7]. The metabolic versatility is an important adaptation mechanism for $M t b$ to thrive in the nutrient-poor macrophage phagosomes during infection. In this section, we will discuss how $M t b$ metabolizes a range of carbon sources during infection.

\subsection{Fatty Acids}

By consensus, fatty acids, rather than carbohydrates, are proposed to be the primary carbon source for $M t b$ during infection. As early as 1956, Segal and Bloch had demonstrated that $M t b$ from lungs of infected mice preferentially metabolize fatty acids ex vivo [20]. Gene expression analysis further revealed the upregulation of $M t b$ genes involved in fatty acid catabolism during infection [21-23]. For instance, mce1, which encodes for a fatty acid transporter, and $l u c A$, which is necessary for Mce1-mediated fatty acid import, are 
upregulated during infection [24]. Using a systematic transposon $M t b$ mutant screen, it was further revealed that mutations in the mce1 locus conferred in vivo growth defects [25]. The requirement of fatty acid transport via Mce1 is further corroborated by fitness defects of $\Delta m c e 1 M t b$ and $M$. bovis bacillus Calmette-Guérin (M. bovis BCG) mutants in infected macrophages [26,27] and mice [28,29]. It is noteworthy that a de novo type I fatty acid synthase (FAS-I) was found to be overexpressed in the mce1 mutant [30], which may serve as a compensatory mechanism for the reduction of fatty acid import by increasing de novo fatty acid synthesis.

$M t b$ is able to metabolize both even-chain and odd-chain fatty acids (Figure 1A, dark blue arrows). During fatty acid catabolism, even-chain fatty acids are broken down to acetyl-coenzyme A (CoA) (Figure 1A, dark blue arrow, solid line) and utilized by the TCA cycle while odd-chain fatty acids are broken down to propionyl-CoA (Figure 1A, dark blue arrow, dashed line). Subsequently, propionyl-CoA must first be converted into a less toxic form before it can be used in the TCA cycle. There are three main mechanisms developed by $M t b$ to counter and detoxify propionate accumulation for its survival (Figure $1 \mathrm{~A})$. The first mechanism occurs via the methylcitrate cycle (MCC) (Figure 1A, green arrows) where isocitrate lyase 1 (Icl1) functions as a methylisocitrate lyase and converts propionyl-CoA to succinate $[31,32]$. The second mechanism is via the vitamin B12-dependent methylmalonyl pathway (MMP) [33] (Figure 1A, dark purple arrows) where propionyl-CoA is first converted to methylmalonyl-CoA and subsequently transformed to succinyl-CoA. The third mechanism involves the diversion of derivatives of propionyl-CoA, such as methylmalonyl-CoA, into the biosynthesis of methyl-branched fatty acids (Figure 1A, light purple arrows), which can be further incorporated into cell wall lipids, including phthiocerol dimycocerosate (PDIM), sulfolipid (SL) and di-and poly-acyl trehaloses (DAT, PAT) [34].

Fatty acid metabolism is clearly not a standalone by itself. Rather, it is intimately linked to central carbon metabolism via the common intermediate, acetyl-CoA, which is directed into the various metabolic branches, including the TCA cycle (Figure 1B, gold arrows), the glyoxylate shunt (Figure 1B, red arrows) and the gluconeogenic pathway (Figure 1). Phosphoenolpyruvate carboxykinase (PEPCK) is essential for growth of $M t b$ on fatty acids and catalyzes the flow from TCA cycle-derived metabolites to gluconeogenic intermediates, highlighting the potential link between fatty acid metabolism and the gluconeogenic pathway [35] (Figure 1A,B). The involvement of the glyoxylate shunt enzymes, isocitrate lyases ( $\mathrm{Icl} 1 / \mathrm{Icl} 2)$, in utilization of fatty acids and its impact on $M t b$ growth and virulence [36] (Figure 1B,C), further suggested the multitude of mechanisms involved in fatty acid utilization for the survival of the bacterium.

\subsection{Cholesterol}

Cholesterol, another lipid-based carbon source, has been established by various studies as a nutrient for $M t b^{\prime}$ s growth during infection [4,37,38]. Although $M t b$ does not synthesize cholesterol, encoded in its genome are genes involved in cholesterol metabolism and transport [4]. Acquisition of host cholesterol through the Mce4 transporter system was found to be crucial for persistence in the lungs of chronically infected animals and for growth within the interferon gamma activated macrophages [4]. Early genetic screens predicted that the mce4 genes, encoding for the Mce4 complex that is required for cholesterol import, was required for $M t b^{\prime}$ s survival when passaged in mice during 2-4 weeks of infection [25]. Lipid uptake coordinator A, LucA, was also found to interact with Mce4 complex to import cholesterol [24], suggesting an overlap between fatty acid and cholesterol uptake during infection.

Several studies have further provided support for the role of host cholesterol in mycobacterial growth and infections. Specifically, $M t b$ genes, $k s h B, f a d A 5$ and $h s a C$, which are involved in cholesterol metabolism, are required for optimum growth and persistence of $M t b$ in vivo [39-41]. Through a chemical screen for inhibitors that target cholesterol metabolism, it was found that cAMP is required for cholesterol utilization by $M t b$ [42]. 
Interestingly, the group of Platt found that macrophages infected with persistent intracellular M. bovis BCG and Mtb resembled the phenotype of Niemann Pick Type C cells, including accumulation of cholesterol and sphingolipids in late endosomal and lysosomal compartments [43], which can serve as a potential store of lipids for Mtb. Evidently, $M t b$ is able to utilize fatty acids and cholesterol from the host during infections. However, whether these lipids serve to fulfill the same or different metabolic requirements remain a topic for further investigation.

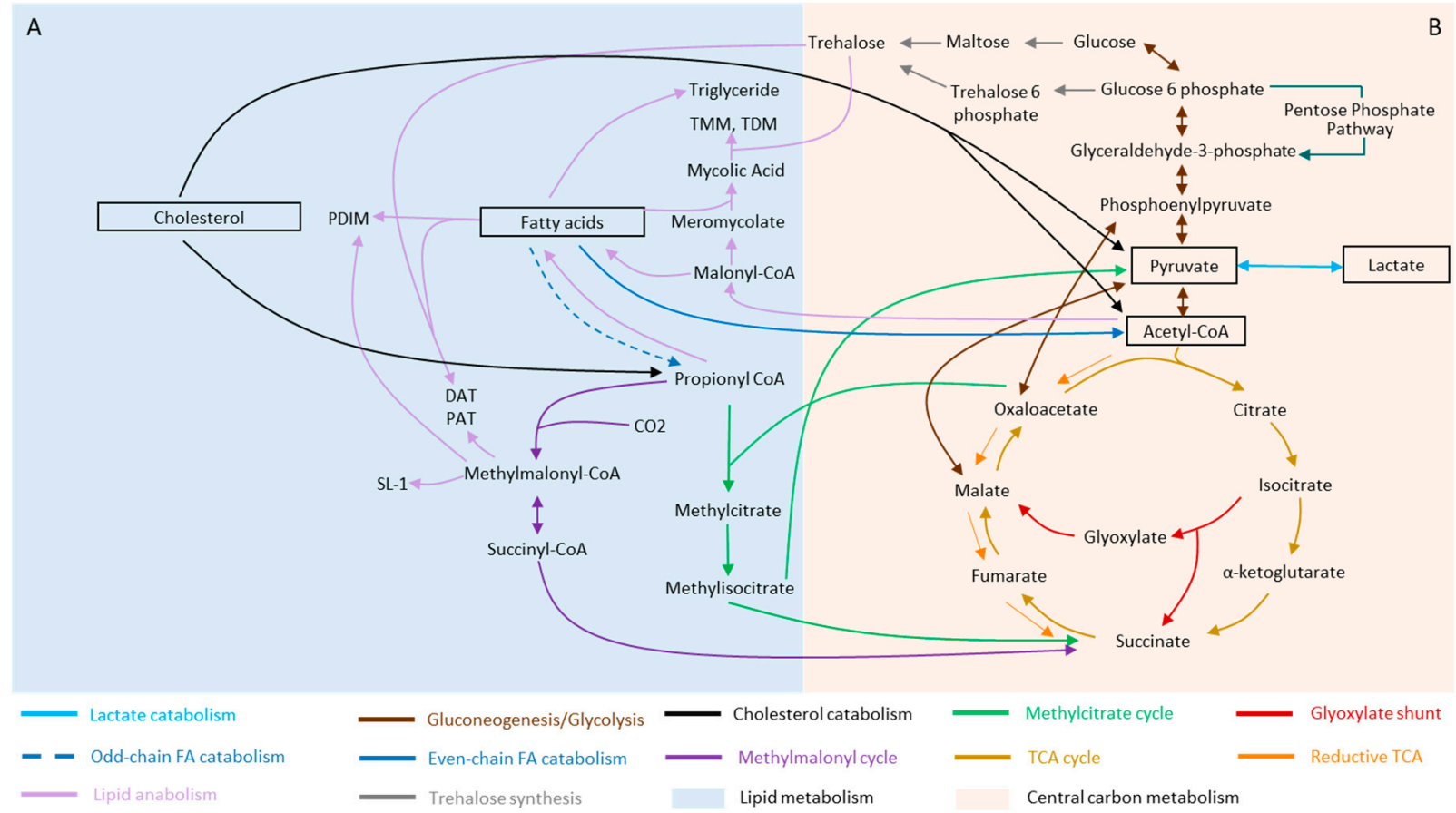

Figure 1. Schematic diagram linking central carbon metabolism (CCM) and lipid metabolism in Mycobacterium tuberculosis $(\mathrm{M} t b)$. (A) Catabolism of cholesterol and fatty acids (dark blue and black arrows) produces a variety of substrates, including succinyl-coenzyme A (CoA), propionyl-CoA and acetyl-CoA, which are channeled into CCM. While acetyl-CoA enters the tricarboxylic acid cycle (TCA) cycle (gold arrows), succinyl-CoA and propionyl-CoA enter the methylmalonyl cycle (dark purple arrows) and methylcitrate cycle (green arrows), respectively. Dashed (- -) dark blue arrow indicates catabolism of odd-chain fatty acids while solid dark blue arrow indicates catabolism of even-chain fatty acids. Fatty acids further serve as building blocks for other lipids, including triglycerides, which are involved in dormancy, while methylmalonyl-CoA serves as precursors of more complex $M t b$ lipids, including sulfolipids, acylated trehalose (light purple arrows). (B) $M t b$ is able to adapt to varying conditions through the diversity of its central carbon metabolism pathways, including the pentose phosphate pathway (dark green arrow), and variations in the TCA cycle. When under favorable conditions, carbon will flow through the classic TCA cycle (gold arrows), favoring the biosynthesis of precursors and generation of adenosine triphosphate (ATP). During infection when the bacterium is exposed to various stress conditions, carbon intermediates can also go through the reductive branch of the TCA cycle (orange arrows) or glyoxylate shunt (red arrows) in $M t b$. These pathways are important for the regeneration of metabolites such as succinate, which is essential for instance in adaptation to hypoxia. During growth, intermediates of the TCA cycle must be withdrawn for the biosynthesis of fatty acids, nucleotide bases and amino acids through gluconeogenesis. These intermediates are replenished to achieve steady levels for normal TCA function by anaplerosis. The anaplerotic node is the metabolic link between glycolysis, gluconeogenesis (dark red arrows) and the TCA cycle (gold arrows) and acts as a switch that directs the flow of carbon distribution within the CCM. An example of anaplerosis is during growth on fatty acids, when the glyoxylate shunt (red arrows) serves to replenish malate via isocitrate lyase and malate synthase. Glucose further serves as a precursor for trehalose (grey arrow), which is a building block of glycolipids. Abbreviations: SL-1 = sulfolipid-1; FA = fatty acid; TCA = tricarboxylic acid cycle, $\mathrm{CoA}=$ coenzyme $\mathrm{A} ; \mathrm{CO}_{2}=$ carbon dioxide; $\mathrm{DAT}=$ diacyl trehalose PAT = poly-acyl trehalose PDIM = phthiocerol dimycocerosate; $\mathrm{TMM}$ = trehalose monomycolate; TDM = trehalose dimycolate. Note: the schematic is a simplified form and do not represent all steps of the biosynthesis and catabolic pathways of the various metabolites. 


\subsection{Lactate and Pyruvate}

Besides the long-established lipid-based diets, a more recent addition to our current knowledge of potential primary carbon sources for $M t b$ is lactate, a metabolite directly linked to pyruvate. The activity of phosphoenolpyruvate carboxykinase, PckA, is essential for utilization of lactate [44]. Further characterization involving the combination of classical microbiology with a "multi-omics" approach consisting of ribonucleic acid (RNA) sequencing (RNA-seq) transcriptomics, proteomics, stable isotopic labeling coupled with mass spectrometry-based metabolomics, led to the findings that lactate and pyruvate metabolism required both the glyoxylate shunt (Figure 1B, red arrows) and the methylcitrate cycle (Figure 1A, green arrows) [45], which were both previously associated with fatty acid metabolism $[31,35,36]$. The requirement for pyruvate, however, depends on the lineage within the Mycobacterium tuberculosis complex (MTBC), in part arising from mutations of $p y k A$, which encodes for pyruvate kinase [46]. While more works are required to further elucidate the contribution of lactate and pyruvate as a major carbon source for $M t b$ during infection and its impact on mycobacterial physiology, the current findings highlighted a common link between fatty acid utilization and metabolism of lactate and pyruvate, which involves the glyoxylate shunt and methylcitrate cycle [44] (Figure 1). This also brings to question whether the previously determined inability to establish infections in $\triangle p c k A$ [35] and $\Delta i c l 1 / 2$ [36] knockout mutants are linked to lactate and pyruvate metabolism, besides lipid metabolism.

Evidently, the metabolism of $M t b$ continues to be a subject of immense interest given its central roles in virulence and growth. Although fatty acids are still believed to be the main carbon source used by the bacterium in vivo and in vitro, it is likely that other nutrients including cholesterol and lactate, and the less well-characterized host-derived sphingomyelin [47] serve to meet distinct metabolic requirements during growth under different conditions. For instance, the acquisition of host cholesterol may play an important role for chronic infection but is not necessary for establishing infection [4]. This implies that during the establishment of infection, other carbon sources play a greater role in supporting the growth of $M t b$, while cholesterol is involved in counteracting the harsh environment during chronic infection. Indeed, the diet of $M t b$ may be influenced by its site of replication and host cell type. In particular, $M t b$ is able to egress from the phagosome to the cytosol, where it will be exposed to a metabolic milieu distinct from the nutrient limiting phagosomal environment [48-50]. Future works involving the determination of metabolite levels in these subcellular components where $M t b$ resides, and labeled metabolite tracing using mass spectrometry or imaging technologies will shed new lights into the precise menu $M t b$ is able to access and utilize for its survival and persistence.

\section{Remodeling of Metabolism during Stress and Dormancy}

As an intracellular bacterium, $M t b$ has evolved strategies to adapt to the varying environments that it colonizes. When exposed to stress conditions, including nutrient starvation [51] and low oxygen [52], $M t b$ is able to switch its metabolism to enter a dormant state while maintaining its adenosine triphosphate (ATP) levels for long term survival within the host [53]. Classical genetics studies have contributed to the identification of factors involved in stress adaptation and dormancy, including DosR, enduring hypoxic response (EHR) and WhiB3, which affect mycobacterial metabolism [54-56]. In more recent years, independent studies on dormancy employing a range of systems of biology approaches, including transcriptomics, proteomics and metabolomics analyses, have revealed differential regulation of metabolic networks linked to the electron transport chain (ETC), energy metabolism and lipid metabolism [57,58]. Understanding the essentiality of metabolism during dormancy is critical for the development of more effective therapy for TB. This section consolidates relevant findings on remodeling of lipid and central carbon metabolism of $M t b$ during stress and dormancy. 


\subsection{Rewiring of Carbon Metabolism during Stress and Dormancy}

One of the mechanisms by which $M t b$ alters its carbon metabolism in times of stress is by controlling the flux of carbon intermediates through the TCA cycle (Figure 1B, gold arrows). Variations in the TCA cycle in $M t b$ reflect its adaptive capability to diverse metabolic niche and needs [59]. Although the $M t b$ genome is annotated to encode a complete TCA cycle [60], $M t b$ lacks the canonical $\alpha$-ketoglutarate dehydrogenase (KDH) [61], suggesting a bifurcated TCA cycle. The reductive branch of the TCA cycle (Figure 1B, orange arrows) is, on the other hand, focused on the production of metabolites such as succinate, which is used to sustain membrane potential, ATP synthesis and anaplerosis [62-64]. In fact, production and metabolism of succinate is critical for the adaptation of $M t b$ to hypoxia [63]. Alterations of succinate and malate levels through the reductive branch of the TCA cycle was also observed when $M t b$ is exposed to antibiotic-induced stress [65], oxygen depletion $[63,66]$ and high salt concentration [67]. The involvement of the reductive branch of the TCA cycle in mycobacterial adaptation was further supported by upregulation of several enzymes involved in this pathway, including fumarate reductase and phosphoenolpyruvate carboxykinase, during hypoxia. In addition, Icl1, which is involved in the glyoxylate shunt, was also upregulated in hypoxic cultures [57] and antibiotics exposure [65]. Taken together, the enzymes of the reductive branch of the TCA cycle may play an essential role in the adaptation of $M t b$ to different types of stresses. This pathway further serves to maintain an energized membrane under anaerobic conditions, through intracellularly generated fumarate that acts as an electron sink [66]. Moreover, the reduction of fumarate may reoxidize reducing equivalents that could favor cometabolism of several carbon sources under oxygen-limiting conditions [66].

Rerouting of carbon metabolism is also observed upstream of the TCA cycle. Specifically, hypoxia-induced metabolic shift towards the pentose-phosphate pathway (PPP) (Figure 1B, dark green arrow) was observed in both Mycobacterium bovis BCG and Mtb $[68,69]$. The PPP serves as a source of reducing equivalents for reductive biosynthesis and the retardation of glycolysis and facilitation of metabolic reprogramming toward the PPP may be associated with achieving a redox balance during stress [69]. This will require further investigations, as the PPP is also a potential source of intermediates for de novo peptidoglycan synthesis, which is reinitiated during recovery from hypoxia [68].

$\mathrm{M} t b$ also undergoes metabolic remodeling when under acidic $\mathrm{pH}$ conditions, which the bacterium frequently encounters within the mycobacterial vacuole. Interestingly, the ability to grow under low $\mathrm{pH}$ is dependent on the carbon sources the bacterium is grown in [70]. It was further demonstrated that the strong induction of genes, including pckA and $i c l 1$, to reroute the distribution of carbon flux through the anaplerotic node is required for promoting growth under acidic conditions. Specifically, PckA connects oxaloacetate to phosphoenolpyruvic acid (PEP) (Figure 1B, dark red arrows), while Icl1 allows the bypassing of the oxidative branch of the TCA cycle and funnel metabolism towards the glyoxylate shunt (Figure 1B, red arrows). The involvement of the anaplerotic node is also evident during nutrient stress, where phosphoenolpyruvate kinase is linked to the production of TCA intermediates from phosphoenolpyruvate [71].

Besides adapting to stress during persistence and dormancy by remodeling central carbon metabolism and rerouting metabolites through variant TCA cycles, $M t b$ can control the flow of carbon metabolites through the trehalose catalytic shift. Trehalose is a nonreducing glucose disaccharide found in $M t b$ and serves as a form of carbon storage [72,73]. It is also a core component of cell surface trehalose monomycolate (TMM) and trehalose dimycolate (TDM). In persister subfractions of in vitro mycobacterial biofilm cultures, trehalose and maltose are diverted from the biosynthesis of cell wall TMM and TDM and are channeled into the biosynthesis of CCM intermediates in order to maintain ATP and antioxidant biosynthetic activities [74]. In addition, the trehalose catalytic shift enables $M t b$ to resist bedaquiline (BDQ)- or carbonyl cyanide m-chlorophenyl hydrazone (CCCP)mediated side effects and promote transitioning into viable but nonculturable cells (VBNCs) following first-line TB drug treatment [74]. This metabolic shift allows Mtb to better adapt 
to its environment as it ensures sufficient carbon flux into energy production. Interestingly, non-replicating and drug tolerant $M t b$ from hypoxic cultures showed downregulation of TMM and TDM and remodeling of trehalose metabolism [57,68,75]. Furthermore, comparative analysis of clinical drug-resistant and drug-sensitive $M t b$ isolates revealed that the trehalose synthase/amylase (TreS)-mediated trehalose catalytic shift was active in extensively drug resistant (XDR)- and totally drug resistant (TDR)- $M t b$ isolates [74]. Together, these studies highlight the involvement of trehalose metabolism remodeling as a possible adaptive process in harsh environment to ensure sufficient ATP production and may be involved in persistence and drug resistance.

\subsection{Lipid Metabolism of Mtb and Its Remodeling during Stress and Dormancy}

When faced with stress, $M t b$ restricts its growth by diversion of carbon metabolism away from growth-promoting pathways such as the TCA cycle to triacylglycerol (TG) synthesis [76], reinforcing the intimate link between carbon and lipid metabolism in $M t b$. Cumulating evidence are available demonstrating the extensive remodeling of mycobacterial lipids, including TG accumulation and cell wall thickening, during stress and dormancy [77]. In this section, we will focus on how key Mtb lipid classes (based on Lipid Maps classification [78,79]) — fatty acyls, glycerolipid, glycerophospholipids and saccharolipidsare modulated during stress and dormancy.

\subsubsection{Fatty Acyls (FA)}

Besides being utilized by $M t b$ as a carbon source and serving as the building blocks of membrane phospholipids, fatty acids can induce changes in the phenotype of $M t b$, resulting in dormancy-like traits. Rodriguez et al. developed an in vitro model where $M t b$ grown in even-length long-chain fatty acids as the sole carbon source acquired slow-growth and drug-tolerant phenotypes that are associated with dormancy [80]. Interestingly, treatment of $M t b$ with exogenous unsaturated fatty acids, including arachidonic acid, was shown to resuscitate dormant $M t b$ [81]. Arachidonic acid is found in human cells but not in $M t b$, and further works are required to elucidate the actual contribution of this host-related lipid in disease reactivation.

Another class of fatty acids that play a significant role in dormancy and reactivation is mycolic acid (MA), which is a unique and structurally complex cell wall lipid present in mycobacteria and closely related species. MA is characterized by a very hydrophobic $\mathrm{C}_{42}$ to $\mathrm{C}_{62}$ fatty acids with $\mathrm{C}_{22}$ to $\mathrm{C}_{26} \alpha$-side chains. MA serves as a precursor for more complex lipids, including TDM and TMM, which together play a significant role in cell wall permeability and regulation of entry of small molecules. Genes involved in mycolic acid synthesis are generally downregulated under hypoxic conditions [82], which is further confirmed at the protein expression level [57]. Using path-seq, Peterson and coworkers revealed that the two mycolic acid desaturases $\operatorname{des} A 1 / \operatorname{des} A 2$ are regulated by MadR, which initially promote cell wall remodeling upon in vitro macrophage infection and, subsequently, reduces mycolate biosynthesis upon entering dormancy [83]. Repression of fatty acid metabolism genes and mycolic acid synthesis genes may be beneficial to dormant $M t b$ as mycolic acid synthesis is costly in terms of energy requirements [82]. During reaeration, proteins involved in fatty acid synthesis, including fatty acid synthases I-III, and mycolate and methyl-branched chains biosynthesis were upregulated [57]. Together, these studies demonstrated that the activity of fatty acids and their remodeling play a significant role in dormancy and reactivation.

\subsubsection{Glycerolipids (GLs)}

GLs can be classified into three subclasses: monoacylglycerides (MG), diacylglycerides (DG) and triacylglycerides (TG). Our knowledge on the functions of TG has been built upon $M t b$ and other Mycobacterium species. TG are mainly used as energy sources by $M t b$ and are broken down by lipases to generate FAs during starvation [84]. Remarkably, the $M t b$ genome consists of 24 members in the "Lip" family, which have been annotated as putative 
esterases or lipases based on the consensus sequence GXSXG characteristic of the $\alpha / \beta$ hydrolase fold family (reviewed in $[85,86]$ ). Amongst these lipases, LipY, which belongs to the hormone-sensitive lipase (HSL) family, is able to break down TG from both host and mycobacterial lipids as shown in M. bovis BCG-infected foamy macrophage models [87]. In addition, when $M t b$ and $M$. bovis BCG are exposed to stress, they accumulate TG [88-90] and the production of TG diverts carbon metabolism away from growth-promoting pathways, thereby restricting the growth of the bacilli [76]. Accumulation of TG and the presence of intracellular lipid inclusion (ILI) is in fact a common hallmark for dormancy. Strikingly, Garton et al. [91] discovered the presence of lipid body-positive mycobacteria in the sputum of samples. Classically, dormant $M t b$ has been associated with the granuloma and the presence of this non-replicating pool of bacterium in sputum raises the question of how this population of dormant bacterium is transmitted.

As an intracellular bacterium, $M t b$ is capable of synthesizing its own TG and deriving the lipid from its host. TG accumulation can be mediated by the fatty acyl-CoA ligase (FACL), an acyl-CoA synthetase [92], and Tgs1, a triglyceride synthase, which is regulated by the dormancy-induced DosR regulon [93]. Upregulation of mycobacterial genes, such as $\operatorname{dos} R, h s p X, i c l 1, \operatorname{tgs} 1$ and $\operatorname{lip} Y$, was observed in $M t b$ within hypoxic lipid-loaded macrophages along with other $M t b$ genes known to be associated with dormancy and lipid metabolism [93]. Using radioisotope and fluorescent labeling, it was shown that Mtb used fatty acids released from host TG for resynthesis of TG within the bacterium. In M. avium, it was demonstrated that host TG in very-low-density lipoprotein (VLDL) was important for ILI formation and growth arrest [94]. Upon the removal of VLDL, ILI declined and cell division of $M$. avium resumed. Breakdown of TG is also evident in $M$. bovis BCG during recovery from hypoxia-induced dormancy, which requires the actions of TG lipase [89], and it is proposed that TG serves as a pool of FA for mycobacterial growth. The mobilization and incorporation of host lipids for the formation of ILI, which occurs during mycobacterial dormancy was further demonstrated by a separate study using exogenous labeled TGs stored in host lipid droplets to track the uptake of FAs and host phospholipids into $M$. marimum, [95]. In addition to serving as an energy source during starvation, or during reactivation of dormant bacterium, TG can also act as an electron sink for balancing cellular metabolism based on the environmental conditions [96].

\subsubsection{Glycerophospholipids (GPs)}

Glycerophospholipids (GPs) are fatty acid diglycerides with a phosphatidyl ester and are major components of the plasma membrane. This membrane lipid class can be further classified into various subclasses including cardiolipin (CL), phophatidylethanolamine (PE), phosphatidylinositol (PI), phosphatidylglycerol (PG), LysoPG and phosphatidylinositol mannoside (PIMs) based on their terminal ester groups or presence of mannoside group(s). GP can serve as potential donors of fatty acids for formation of TG in ILI [95]. However, there are limited studies on the exact roles of GP in dormancy. Nonetheless, modulation of membrane fluidity through alterations of phospholipid composition serves as a protective mechanism for the bacilli when exposed to varying environmental stresses. For instance, when $M t b$ is exposed to physiologic salt concentration, which is generally higher than laboratory culture conditions, plasma membrane associated PE and PG levels decreased [67], while an increase in PIMs with higher acylation state such as $\mathrm{Ac}_{2} \mathrm{PIM}_{2}$ and $\mathrm{Ac}_{2} \mathrm{PIM}_{6}$ was observed [67].

\subsubsection{Saccharolipids}

Saccharolipids are lipids in which fatty acids are linked directly to a sugar backbone and are found in various organisms besides $M t b$ [97]. Extensive structural diversity exists in saccharolipids due to the variations in both the carbohydrate and lipid moieties. For instance, sulfolipids (SL) and sulphoglycolipids (SGL) possess a sulfur-containing functional group in the sugar moiety. $M t b$ can alter its SL and SGL composition during persistence [70] and dormancy [75]. Transcriptional profiling data of $M t b$, in both glycerol and pyruvate at 
pH 5.7, identified strong induction in the mmpL8-pks2 operon [70], which has been shown to control the synthesis of SL [98]. Using a radiolabeled ${ }^{14} \mathrm{C}$-acetate tracing experiment at $\mathrm{pH} 7$ and $\mathrm{pH}$ 5.7, it was demonstrated that accumulation of SL occurred in wildtype Mtb but not in $\triangle p h o P R$ mutants [70]. This confirmed the effects of acidic $\mathrm{pH}$ in remodeling lipid metabolism through stimulation PhoPR and promotion of SL accumulation. In hypoxiainduced dormancy, the biosynthetic genes for SL, acylated trehalose (PAT/DAT), PDIMs and methylmalonyl are downregulated [75]. Conversely, these genes are induced upon reactivation and reaeration [75], confirming the ability of $M t b$ to remodel saccharolipids and other lipids during its transition towards dormancy or the active state.

Collectively, numerous studies have demonstrated that $M t b$ undergoes extensive metabolic remodeling when under stress and during dormancy. Metabolic remodeling is a survival strategy developed by the bacterium and a detailed understanding of the functions of metabolism under varying conditions can provide novel insights into potential points of interventions to eradicate the persistent and deadly bacterium.

\section{Metabolism in Drug Discovery}

The critical roles of metabolism in mycobacterial growth, virulence and dormancy, in combination with the differences in metabolic pathways between $M t b$ and humans, make mycobacterial metabolism an attractive target for therapeutic development. With the emergence of drug resistant $M t b$, there is now an urgent need for novel drugs for treatment of MDR- and XDR-TB. Here, we will summarize a range of antimycobacterial strategy that targets metabolism, including oxidative phosphorylation and lipid metabolism (Figure 2). More extensive reviews on this topic can be found in various publications $[17,99-102]$.

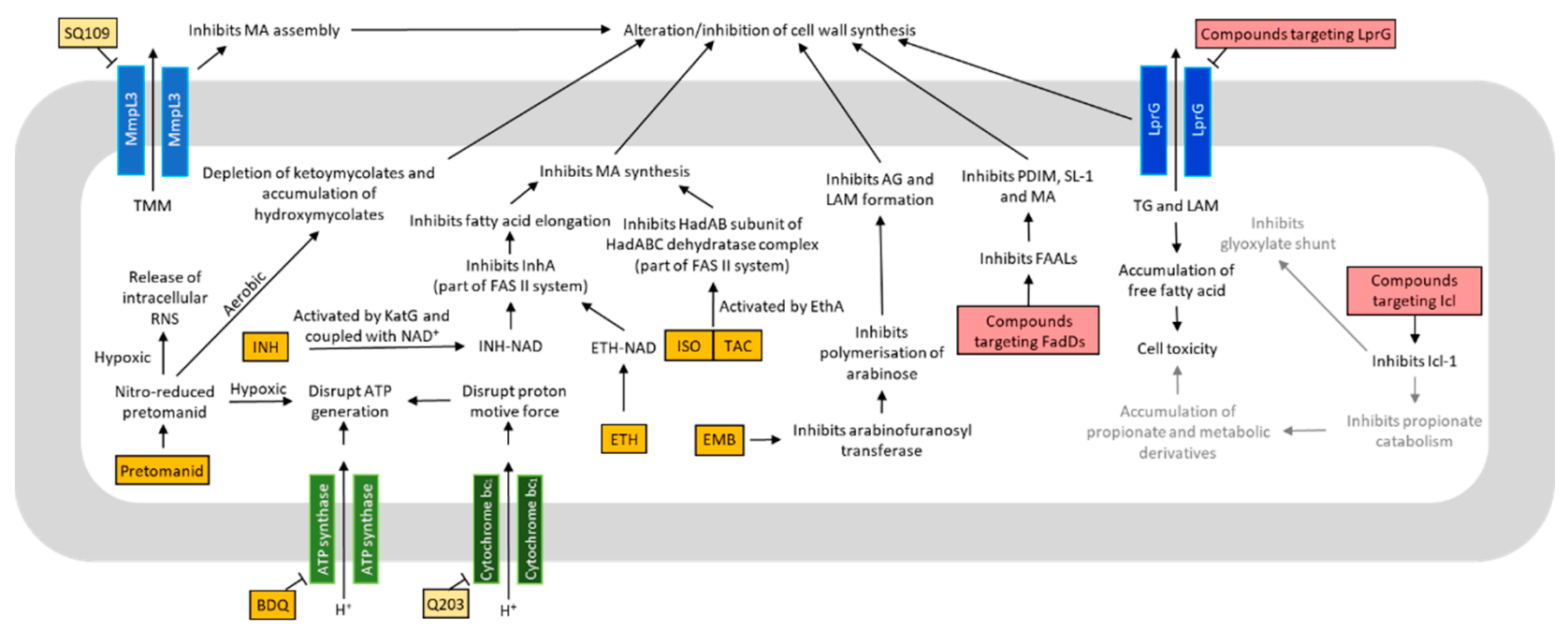

Figure 2. Mechanisms of action of various antituberculosis (anti-TB) drugs and compounds targeting the metabolism of Mycobacterium tuberculosis $(M t b)$. Many anti-TB drugs and compounds target different aspects of metabolism, and consequently lead to bacteriostasis or bactericidal effects. Some anti-TB drugs and compounds may share the same cellular targets. Others may act on different targets, which can affect common metabolic pathway(s). Drugs approved for treatment are colored in orange. Compounds undergoing clinical trials are colored in yellow. Compounds still in vitro developmental phase are colored in red. Text colored in grey are the proposed mechanisms. Abbreviations: $\mathrm{INH}=$ isoniazid; $\mathrm{ETH}=$ ethionamide; ISO = isoxyl; TAC = thioacetazone; $\mathrm{BDQ}=$ bedaquiline; FadDs = fatty acid adenylating enzymes; $\mathrm{ICL}=$ isocitrate lyase; $\mathrm{EMB}=$ ethambutol; $\mathrm{ATP}=$ adenosine triphosphate; NAD = nicotinamide adenine dinucleotide; LprG = Lipoarabinomannan carrier protein LprG; EthA = flavin adenine dinucleotide (FAD)-containing monooxygenase; HadAB = $\beta$-hydroxyacyl-ACP dehydratase HadAB complex; KatG = catalase-peroxidase; FAS II = type II fatty acid synthase; InhA = enoyl-ACP reductase; RNS = reactive nitrogen species; AG = arabinogalactan; TG = triacylglycerol; LAM = lipoarabinomannan; FAAL = fatty acyl AMP ligase; PDIM = phthiocerol dimycocerosates; SL-1 = sulfolipid-1; $\mathrm{MA}=$ mycolic acid. 


\subsection{Oxidative Phosphorylation and ATP Production}

The central energy currency among all bacteria species, ATP, is resynthesized via various mechanisms, which differ greatly between differentorganisms. For example, the enterobacteria regenerate nicotinamide adenine dinucleotide (NAD) pool by fermentation when grown on carbohydrates and bypasses the need of oxidative phosphorylation [103,104]. $M t b$, on the other hand, is devoid of fermentative lactate dehydrogenase, making oxidative phosphorylation strictly necessary for growth [105]. In fact, during dormancy, although the bacterium is in general under a state of reduced metabolism, it continues to synthesize ATP, albeit at lowered levels, for its long-term survival. Hence, the oxidative phosphorylation pathway serves as a promising drug target for both replicating and non-replicating $M t b$. Indeed, bedaquiline (BDQ), a drug that targets the $\mathrm{F}_{0} \mathrm{~F}_{1}$ ATP synthase $[106,107]$, was approved by the FDA in 2012 for the treatment of MDR-TB [108]. Critically, BDQ is active against dormant $M t b$ [109]. With increased recognition of drugs targeting the electron transport chain (ETC) as being effective against MDR- and XDR-M $t b$ [53], other enzymes involved in oxidative phosphorylation have gained interest as potential drug targets against $M t b$ [110-115]. One such potential drug target is the cytochrome bc $c_{1}$ complex [114,115]. Q203, an inhibitor of the cytochrome bc 1 complex that has completed a Phase 2 clinical trial and is in the pipeline for further development [116].

As research in drug development against $M t b$ advances, it is also important to appreciate the influence of different carbon substrates on the TCA cycle and oxidative phosphorylation and ultimately drug efficacy. This can be exemplified by the actions of BDQ, which is enhanced when $M t b$ is grown on non-fermentable energy sources, including lipids [117]. Interestingly, Greenwood et al. showed that BDQ accumulated primarily in host cell lipid droplets, which served as a reservoir for the transfer of BDQ when utilizing host lipids [118]. Alterations of host lipids in turn affected the efficacy of BDQ against intracellular $M t b$, highlighting the potential of host cell lipid droplets as an effective delivery system for improving efficacy of anti-TB drugs. The link between carbon sources and drug efficacy is further evident in Q203, which acts through inhibition of cytochrome $\mathrm{bc}_{1}$ activity and consequently ATP synthesis [119]. When supplemented with glycerol, it was discovered that $M t b$ significantly upregulated its Cyt-bd terminal oxidase, hence providing an alternative respiratory route and diminishes the effectiveness of cytochrome $\mathrm{bc}_{1}$ inhibitors such as Q203 [120]. As glycerol is commonly used in standard laboratory mycobacterial culture media, this research finding highlights the need for more attention in defining suitable conditions for drug screening. The impetus for research on this topic is further exacerbated by the inappropriate use of rich bacterial broth in studies that seeks to mimic the physiology of the site of infection of $M t b$, which on the contrary is nutrient limiting. This has in fact been one of the most cited reasons for the failure of drug discovery programs [121] and establishment of in vitro conditions representative of in vivo infection and dormancy is critical for TB drug discovery.

\subsection{Lipid Metabolism}

Targeting mycobacterial lipid metabolism as a point of therapeutic intervention dates back to as early as the 1950s, with the discovery of isoniazid (INH) [122,123]. INH, which targets the biosynthesis of MA [124], the major component of mycobacterial cell wall, continues to be one of the first line drugs used for TB treatment. Newer drugs that disrupt MA metabolism, albeit through different mechanisms, were approved over the last 50 years. These drugs include ethionamide (ETH) [125], isoxyl (ISO) [126] and thioacetazone (TAC) [127]. Alternative targets of lipid metabolism include biosynthesis or degradation of fatty acids and metabolites, including fatty acid adenylating enzymes (FadDs) [128,129] and isocitrate lyases. Inhibition of Icl has been well-studied with several known inhibitors including 3-nitropropionate, 3-bromopyruvate [130], phthalazines [131,132], hydrazones [133] and 5-nitro-2,6-dioxohexahydro-4-pyrimidinecarboxamides [134]. However, these are currently experimental compounds and have not advanced into any clinical trials and more research is certainly required to optimize potential leads. 
Other than targeting the biosynthesis of lipids or conversion into energy, the transport of lipids into and out of $M t b$ can also be an attractive point of intervention. One such drug target is the trehalose monomycolate exporter MmpL3, which is embedded on the inner membrane and acts as a cytoplasmic membrane transporter for TMM to the cell wall [135,136]. SQ109, a 1,2-diamine related to ethambutol, has completed a Phase II study involving drug-sensitive TB patients in 2016 [137]. Though its mode of action remains unclear, studies have demonstrated that SQ109 targets MmpL3, which directly inhibits TDM production. This in turn leads to the failure of attaching mycolates to arabinogalactan and interference with cell wall assembly [135]. Another transporter for lipids that is a drug target of interest is the lipoarabinomannan carrier protein LprG, which is involved in exporting triacylated lipids, such as TG and lipoglycans, such as lipoarabinomannan, to the mycomembrane $[138,139]$. In vivo studies have shown that LprG is essential for $M t b$ to establish infection [138], highlighting its potential as a drug target for treatment of infection by multidrug resistant $M t b$.

Despite the overwhelming need for novel anti-TB drugs, drug development in general is full of challenges, risks and failures. In fact, an earlier study by the group of David Russell involving a screen of compounds with anti-TB effects had clearly demonstrated stark differences in potency of compounds when using laboratory culture media containing glucose and oleic acid, in comparison to $M t b$-infected macrophages [42]. This further reinforced the confounding factor we raised, that is, the appropriateness of the carbon sources utilized in in vitro screens, which can influence drug efficacy $[117,119]$. With the improved understanding of mycobacterial metabolism during the host-pathogen interaction, better designs of drug screening assays can be established for discovery new therapeutic regimes for TB.

\section{Systems Biology Methodology and Novel Applications in Mtb Research}

There is no doubt that the metabolic versatility of $M t b$ is critical for infection and is one of the mechanisms it adopts to overcome the actions of antibiotics and stress. With the advent of omics technologies, we are in a better position to obtain a more coherent view on mycobacterial metabolism $[6,57,58,75]$, including understanding the (1) intimate links between lipid and central carbon metabolic networks, (2) interactions between two organisms, the human host and the bacterium and (3) heterogeneity of bacterial population. The latter is greatly facilitated by the recent boom in single-cell technology. In this section, we will discuss more recent advances and applications of systems biology approaches to delineate complex networks during $M t b$ infection and dormancy.

Infection involves the intimate interactions of the host and the pathogen, and advancement in transcriptomics, specifically development of dual-RNA sequencing, has enabled the analysis of both the pathogen and host cells from infected samples. Application of dual-RNA sequencing has recently led to the discovery of a divergent transcriptional response of $M t b$ when comparing infection within alveolar macrophages and interstitial macrophages [140]. Mtb growth is sustained in alveolar macrophages where the bacilli have increased access to iron and fatty acids, while in interstitial macrophages, Mtb growth is restricted due to a high level of nitric oxide and iron sequestration. These findings emphasize the significance of the cell-type dependent metabolic interface in supporting $M t b$ growth in permissive host macrophages and restricting $M t b$ growth in nonpermissive host cells. Path-seq, which was developed more recently to overcome the sensitivity limits of dual-RNA sequencing, enables the analysis of minute amounts of $M t b$ transcripts within up to million-fold excess host RNA [83]. Path-seq analysis of $M t b$ infection using an animal model revealed a novel transcriptional program for mycobacterial cell wall remodeling when $M t b$ infects alveolar macrophages in mice [83]. Specifically, the mycolic acid desaturase regulator, MadR, was found to be involved in the transcriptional modulation of mycolic acid desaturases, which in turn led to cell wall remodeling during initial infection and entry into dormancy. These technologies are clearly extremely powerful for studies 
of intracellular $M t b$, which factors in the effects of the host environment, in contrast to in vitro models.

The integration of multiple omics technologies further contributes to a comprehensive view of the transcriptional and metabolic networks of $M t b$ infection and dormancy. Vrieling and coworkers demonstrated with a combination of untargeted and targeted metabolomics approach that $M t b$ infection resulted in elevated intracellular levels of NAD, creatine, creatine phosphate and glutathione compared to uninfected macrophages [141]. From metabolomics alone, it would be impossible to conclude whether changes in these metabolites are due to changes in the enzymatic level or transcriptional regulation level. Within the same study, the authors further performed RNA-sequencing which revealed the altered gene expression of the key metabolic enzyme involved in NAD, creatine, glucose and glutamine metabolism in Mtb-infected M2 macrophages [141]. Combining both transcriptomics and metabolomics, it can clearly be concluded that $M t b$ infection modulates host macrophage metabolic pathways and the link between the exact genes involved in the observed metabolome changes can be established. The metabolic networks of $M t b$ and infected host cells were established by Zimmermann and coworkers through a combination of dual-RNA sequencing and metabolic flux balance analysis. In this integrated omics study, the research group revealed that $M t b$ can coutilize up to 33 different nutrients during early macrophage infections [6]. These metabolites are funneled to specific processes, with three predicted for biomass production, and the rest for energy production and precursor formation. Given that metabolism is a rapid process, we propose that lipidome- and/or metabolome-wide ${ }^{13} \mathrm{C}$ flux analysis can be further applied to capture dynamic features in real time, including the rate of synthesis, interconversion and degradation of lipids and metabolites [7,142] during infection and dormancy. Besides the derivation of novel mechanistic insights from -omics based approaches, transcriptome and metabolome-based markers can serve as potential markers for prediction of TB progression [143,144].

One of the bottlenecks of systems scale analyses of metabolites and lipids are the chemical diversity of these biomolecules, which limits the coverage of the metabolome and lipidome. The applications of lipidomics and metabolomics in mycobacterial research is increasingly common $[6,145,146]$ and in fact databases for $M t b$ lipids were previously established to facilitate identification of mycobacterial lipids $[79,147]$. To expand on the coverage of metabolomes, a multiplatform approach can be undertaken, for instance by using nuclear magnetic resonance and mass spectrometry, or to employ distinct separation techniques, including chromatography or ion mobility, to capture metabolite subsets, which vary in their specific physiochemical properties. Such a combinatorial approach allows higher levels of metabolite coverage, sensitivity and specificity as compared to the conventional single platform approach [148]. Fernández-García et al. combined time-offlight (ToF) mass spectrometry coupled to capillary electrophoresis, gas chromatography and liquid chromatography, to capture the global metabolome changes in the lungs of $M t b$-infected mice. This enabled the identification of various host-associated metabolic pathways linked to the progression of TB in the mouse model [149]. Metabolomics can be further applied to studies of mechanisms of actions of previously uncharacterized antimicrobial compounds [150], characterization of vaccine candidates [151] and have potential in drug discovery programs of $M t b$ [152].

Another exciting development, which can have significant impact on mycobacterial research is the advances in single-cell technologies. Within an infection, the bacterial population exhibits phenotypic variations, including survival, clearance, persistence and host death, which suggest that heterogeneity of cellular behavior $[153,154]$. Single-cell based technology when coupled with omics approaches can offer a higher resolution to decipher the heterogeneity within bacterial population. Maglica, Özdemir and McKinney developed a combinatorial method comprising of high-throughput microfluidics and automated microscopy to explore single-cell tracking of intracellular ATP in live M. smegmatis. This approach has advanced studies of bacterial energy metabolism in response to drug treatment at an individual cell level $[155,156]$. Specifically, it was discovered that $M$. 
smegmatis persisters are able divide in the presence of INH and exist in a dynamic state of balanced division and death due to stochastic pulses in KatG expression and consequently INH activation [156]. While single-cell tracking has contributed to substantial insights into mycobacterial metabolism during drug responses and persistence, the combination of the technology with omics approaches is technically more challenging. The use of singlecell transcriptomics on $M t b$ has met little success due to the trace amounts of transcripts below detection levels. Nonetheless, the implementation of single-cell transcriptomics on host cells have led to novel insights in interindividual variations in responses to ТВ infection [157] and identification of markers to discriminate between healthy controls to latent TB infection and active TB [158]. Future advances in the technology to capture the transcriptome and metabolome of $M t b$ at the single cell level will certainly expand our knowledge on the physiology of this deadly pathogen.

Our discussion on the metabolic versatility and diversity of $M t b$ will not be complete without acknowledging the natural genetic and metabolic variations of $M t b$ isolates circulating in the world. Population genomics of $M t b$ has provided strong evidence of the genotypic differences between M. tuberculosis complex (MTBC), which is classified into seven lineages based on their genomes [159]. Interestingly, within lineage 2, the hypervirulent Beijing sublineage was shown to accumulate TG, as a result of constitutively upregulation of DosR dormancy regulon $[160,161]$. Lipidomics and metabolomics analyses of MTBC isolates further confirmed the metabolic diversity of MTBC [162,163]. To unravel the genetic basis for the metabolic diversity of MTBC, the group of Gagneux developed an approach for integration of genomics and metabolomics data to identify mutations that are associated with strain-specific metabolic adaptive capacity and vulnerability [162]. The integrative omics approach has also led to the discovery of the genetic basis of baseline differences in susceptibility to the antibiotic para-aminosalicylic acid. Collectively, the applications of systems biology technologies and their integration are extremely powerful for research on $\mathrm{TB}$, which involves the complex interactions of the bacterium with its host and environment.

One of the promising aspects with the increased data generation using omics technologies is the possibility to integrate data from the same experimental model(s), which is produced by different approaches and/or performed by independent research groups. The sharing of these omics data can hence make a major contribution to the field of integrative omics as research groups can capitalize on published data that is made publicly available to derive deeper insights into the biology of $M t b$. For instance, to investigate how the cyclic adenosine $3^{\prime}, 5^{\prime}$-monophosphate (cAMP) receptor protein (CRP) is linked to downstream metabolic changes, Liu et al. performed metabolomics and stable isotope tracing and compared the metabolome of wild type Mtb and crp deletion mutant [164]. Their data suggested the regulatory roles of CRP in nitrogen metabolism and peptidoglycan synthesis, which was corroborated by mining a previously published transcriptomics data [165]. This is made possible with data sharing through various platforms, including the National Centre of Biotechnology Information (NCBI)'s GEO Datasets [166,167], BioCyc's Mtb pathway/genome databases [168], the Pathosystems Resource Integration Center (PATRIC) [169], the MycoBrowser [170] and European Bioinformatics Institute's Metabolights [171]. However, data sharing remains a major bottleneck due to the lack of standardization of experimental models and data structure and should be handled with caution. The problems arising from integration of -omics data from different research groups has been addressed in a review by Furness [172]. Nonetheless, a recent initiative has been made by the group of Gagneux, to define a reference set of genetically wellcharacterized MTBC isolates, spanning all seven known human-adapted MTBC [173]. This MTBC clinical strain reference set can be used by any research groups to study the impact of phylogenetic differences on phenotypes and physiology of MTBC. With the efforts towards harmonization through the clinical strain collection and data collection using various technologies, we anticipated that such systematic and detailed analyses will 
improve our understanding of TB and contribute to the development of new approaches to control the disease.

\section{Conclusions}

$M t b$ can metabolize multiple carbon sources simultaneously and adapt its metabolism to support its growth and survival under varying conditions. While it is known that $M t b$ favors the usage of host lipids in vivo, new lines of evidence suggest alternative carbon sources, including lactate, pyruvate and sphingolipids, as potential requirements for its growth and virulence. The metabolic versatility of $M t b$ has also contributed to the bacilli's ability to persist and remain dormant in host macrophages, a stage that the bacterium exhibits low metabolic rates and is phenotypically resistant to antibiotics. Dynamic metabolic remodeling is also involved in the promotion of growth during resuscitation of $M t b$ from the non-replicative state. Hence, it is paramount to understand the metabolism of $M t b$, given its implications on infection, antibiotics efficacy and potential in novel therapeutics development. This review also discussed recent advances in systems biology approaches and its applications in unraveling the complexity of the metabolic networks involved in infection and bacterial physiology. With the growing availability of large-scale datasets, a more concerted effort in the scientific community to share data will facilitate the integration of the biological networks of $M t b$ to understand the complexity of metabolism during host-pathogen interactions and to unravel insights into $M t b$ biology. A more refined understanding of the metabolism of $M t b$, which takes into consideration its in vivo conditions and its natural genetic and phenotypic variations, is instrumental for future research. Collectively, a consolidated effort involving systems biology research of MTBC clinical isolates can facilitate identification of more effective targets to overcome infections by this genetically and phenotypically diverse pathogen.

Author Contributions: Conceptualization, D.P.S.C. and X.L.G.; writing-original draft preparation, D.P.S.C. and X.L.G.; writing-review and editing, D.P.S.C. and X.L.G.; supervision, X.L.G. All authors have read and agreed to the published version of the manuscript.

Funding: Work in the laboratory of X.L.G. is supported by the Nanyang Assistant Professorship Startup Grant from Lee Kong Chian School of Medicine, Nanyang Technological University Singapore; and the Ministry of Education (MOE) Tier 2 grant (MOE2017-T2-1-042). D.P.S.C. is supported by a Nanyang Technological University Graduate Research Scholarship.

Conflicts of Interest: The authors declare no conflict of interest.

\section{References}

1. World Health Organization. Global Tuberculosis Report 2019; World Health Organization: Geneva, Switzerland, 2019.

2. Cambier, C.J.; Falkow, S.; Ramakrishnan, L. Host evasion and exploitation schemes of Mycobacterium tuberculosis. Cell 2014, 159, 1497-1509. [CrossRef] [PubMed]

3. Cohen, A.; Mathiasen, V.D.; Schön, T.; Wejse, C. The global prevalence of latent tuberculosis: A systematic review and metaanalysis. Eur. Respir. J. 2019, 54, 1900655. [CrossRef] [PubMed]

4. Pandey, A.K.; Sassetti, C.M. Mycobacterial persistence requires the utilization of host cholesterol. Proc. Natl. Acad. Sci. USA 2008, 105, 4376-4380. [CrossRef] [PubMed]

5. De Carvalho, L.P.S.; Fischer, S.M.; Marrero, J.; Nathan, C.; Ehrt, S.; Rhee, K.Y. Metabolomics of Mycobacterium tuberculosis reveals compartmentalized co-catabolism of carbon substrates. Chem. Biol. 2010, 17, 1122-1131. [CrossRef]

6. Zimmermann, M.; Kogadeeva, M.; Gengenbacher, M.; McEwen, G.; Mollenkopf, H.-J.; Zamboni, N.; Kaufmann, S.H.E.; Sauer, U. Integration of Metabolomics and Transcriptomics Reveals a Complex Diet of Mycobacterium tuberculosis during Early Macrophage Infection. MSystems 2017, 2, 1-18. [CrossRef]

7. Beste, D.J.V.; Nöh, K.; Niedenführ, S.; Mendum, T.A.; Hawkins, N.D.; Ward, J.L.; Beale, M.H.; Wiechert, W.; McFadden, J. ${ }^{13}$ C-flux spectral analysis of host-pathogen metabolism reveals a mixed diet for intracellular Mycobacterium tuberculosis. Chem. Biol. 2013, 20, 1012-1021. [CrossRef]

8. Gengenbacher, M.; Kaufmann, S.H. Mycobacterium tuberculosis: Success through dormancy. FEMS Microbiol. Rev. 2012, 36, 514-532. [CrossRef]

9. Caño-Muñiz, S.; Anthony, R.; Niemann, S.; Alffenaar, J.-W.C. New Approaches and Therapeutic Options for Mycobacterium tuberculosis in a Dormant State. Clin. Microbiol. Rev. 2018, 31, e00060-00017. [CrossRef] 
10. Chao, M.C.; Rubin, E.J. Letting Sleeping dos Lie: Does Dormancy Play a Role in Tuberculosis? Annu. Rev. Microbiol. 2010, 64, 293-311. [CrossRef]

11. Lipworth, S.; Hammond, R.J.H.; Baron, V.O.; Hu, Y.; Coates, A.; Gillespie, S.H. Defining dormancy in mycobacterial disease. Tuberculosis 2016, 99, 131-142. [CrossRef]

12. Lewis, K. Persister Cells. Annu. Rev. Microbiol. 2010, 64, 357-372. [CrossRef] [PubMed]

13. Ehrt, S.; Schnappinger, D.; Rhee, K.Y. Metabolic principles of persistence and pathogenicity in Mycobacterium tuberculosis. Nat. Rev. Microbiol. 2018, 16, 496-507. [CrossRef] [PubMed]

14. Stokes, J.M.; Lopatkin, A.J.; Lobritz, M.A.; Collins, J.J. Bacterial Metabolism and Antibiotic Efficacy. Cell Metab. 2019, 30, 251-259. [CrossRef] [PubMed]

15. Shetye, G.S.; Franzblau, S.G.; Cho, S. New tuberculosis drug targets, their inhibitors, and potential therapeutic impact. Transl. Res. 2020, 220, 68-97. [CrossRef] [PubMed]

16. Lee, B.S.; Sviriaeva, E.; Pethe, K. Targeting the cytochrome oxidases for drug development in mycobacteria. Prog. Biophys. Mol. Biol. 2020, 152, 45-54. [CrossRef] [PubMed]

17. Bailo, R.; Bhatt, A.; Aínsa, J.A. Lipid transport in Mycobacterium tuberculosis and its implications in virulence and drug development. Biochem. Pharm. 2015, 96, 159-167. [CrossRef] [PubMed]

18. Flynn, J.L.; Chan, J.; Lin, P.L. Macrophages and control of granulomatous inflammation in tuberculosis. Mucosal Immunol. 2011, 4, 271-278. [CrossRef]

19. Görke, B.; Stülke, J. Carbon catabolite repression in bacteria: Many ways to make the most out of nutrients. Nat. Rev. Microbiol. 2008, 6, 613-624. [CrossRef]

20. Bloch, H.; Segal, W. Biochemical differentiation of Mycobacterium tuberculosis grown in vivo and in vitro. J. Bacteriol. 1956, 72, 132-141. [CrossRef]

21. Schnappinger, D.; Ehrt, S.; Voskuil, M.I.; Liu, Y.; Mangan, J.A.; Monahan, I.M.; Dolganov, G.; Efron, B.; Butcher, P.D.; Nathan, C.; et al. Transcriptional Adaptation of Mycobacterium tuberculosis within Macrophages: Insights into the Phagosomal Environment. J. Exp. Med. 2003, 198, 693-704. [CrossRef]

22. Talaat, A.M.; Lyons, R.; Howard, S.T.; Johnston, S.A. The temporal expression profile of Mycobacterium tuberculosis infection in mice. Proc. Natl. Acad. Sci. USA 2004, 101, 4602-4607. [CrossRef] [PubMed]

23. Rohde, K.H.; Veiga, D.F.T.; Caldwell, S.; Balázsi, G.; Russell, D.G. Linking the transcriptional profiles and the physiological states of Mycobacterium tuberculosis during an extended intracellular infection. PLoS Pathog. 2012, 8, e1002769. [CrossRef] [PubMed]

24. Nazarova, E.V.; Montague, C.R.; La, T.; Wilburn, K.M.; Sukumar, N.; Lee, W.; Caldwell, S.; Russell, D.G.; VanderVen, B.C. Rv3723/LucA coordinates fatty acid and cholesterol uptake in Mycobacterium tuberculosis. eLife 2017, 6, e26969. [CrossRef] [PubMed]

25. Sassetti, C.M.; Rubin, E.J. Genetic requirements for mycobacterial survival during infection. Proc. Natl. Acad. Sci. USA 2003, 100, 12989. [CrossRef] [PubMed]

26. McCann, J.R.; McDonough, J.A.; Sullivan, J.T.; Feltcher, M.E.; Braunstein, M. Genome-wide identification of Mycobacterium tuberculosis exported proteins with roles in intracellular growth. J. Bacteriol. 2011, 193, 854-861. [CrossRef] [PubMed]

27. Stewart, G.R.; Patel, J.; Robertson, B.D.; Rae, A.; Young, D.B. Mycobacterial mutants with defective control of phagosomal acidification. PLoS Pathog. 2005, 1, 269-278. [CrossRef]

28. Gioffré, A.; Infante, E.; Aguilar, D.; Santangelo, M.D.1.P.; Klepp, L.; Amadio, A.; Meikle, V.; Etchechoury, I.; Romano, M.I.; Cataldi, A.; et al. Mutation in mce operons attenuates Mycobacterium tuberculosis virulence. Microbes Infect. 2005, 7, 325-334. [CrossRef]

29. Joshi, S.M.; Pandey, A.K.; Capite, N.; Fortune, S.M.; Rubin, E.J.; Sassetti, C.M. Characterization of mycobacterial virulence genes through genetic interaction mapping. Proc. Natl. Acad. Sci. USA 2006, 103, 11760-11765. [CrossRef]

30. Queiroz, A.; Medina-Cleghorn, D.; Marjanovic, O.; Nomura, D.K.; Riley, L.W. Comparative metabolic profiling of mce1 operon mutant vs wild-type Mycobacterium tuberculosis strains. Pathog. Dis. 2015, 73. [CrossRef]

31. Muñoz-Elías, E.J.; Upton, A.M.; Cherian, J.; McKinney, J.D. Role of the methylcitrate cycle in Mycobacterium tuberculosis metabolism, intracellular growth, and virulence. Mol. Microbiol. 2006, 60, 1109-1122. [CrossRef]

32. Gould, T.A.; van de Langemheen, H.; Muñoz-Elías, E.J.; McKinney, J.D.; Sacchettini, J.C. Dual role of isocitrate lyase 1 in the glyoxylate and methylcitrate cycles in Mycobacterium tuberculosis. Mol Microbiol. 2006, 61, 940-947. [CrossRef] [PubMed]

33. Savvi, S.; Warner, D.F.; Kana, B.D.; McKinney, J.D.; Mizrahi, V.; Dawes, S.S. Functional Characterization of a Vitamin B12Dependent Methylmalonyl Pathway in Mycobacterium tuberculosis: Implications for Propionate Metabolism during Growth on Fatty Acids. J. Bacteriol. 2008, 190, 3886. [CrossRef] [PubMed]

34. Minnikin, D.E.; Kremer, L.; Dover, L.G.; Besra, G.S. The Methyl-Branched Fortifications of Mycobacterium tuberculosis. Chem. Biol. 2002, 9, 545-553. [CrossRef]

35. Marrero, J.; Rhee, K.Y.; Schnappinger, D.; Pethe, K.; Ehrt, S. Gluconeogenic carbon flow of tricarboxylic acid cycle intermediates is critical for Mycobacterium tuberculosis to establish and maintain infection. Proc. Natl. Acad. Sci. USA 2010, 107, 9819-9824. [CrossRef] [PubMed]

36. Muñoz-Elías, E.J.; McKinney, J.D. Mycobacterium tuberculosis isocitrate lyases 1 and 2 are jointly required for in vivo growth and virulence. Nat. Med. 2005, 11, 638-644. [CrossRef] [PubMed]

37. Brzostek, A.; Pawelczyk, J.; Rumijowska-Galewicz, A.; Dziadek, B.; Dziadek, J. Mycobacterium tuberculosis is able to accumulate and utilize cholesterol. J. Bacteriol. 2009, 191, 6584-6591. [CrossRef] 
38. Griffin, J.E.; Pandey, A.K.; Gilmore, S.A.; Mizrahi, V.; McKinney, J.D.; Bertozzi, C.R.; Sassetti, C.M. Cholesterol catabolism by Mycobacterium tuberculosis requires transcriptional and metabolic adaptations. Chem. Biol. 2012, 19, 218-227. [CrossRef]

39. Hu, Y.; Van Der Geize, R.; Besra, G.S.; Gurcha, S.S.; Liu, A.; Rohde, M.; Singh, M.; Coates, A. 3-Ketosteroid 9 $\alpha$-hydroxylase is an essential factor in the pathogenesis of Mycobacterium tuberculosis. Mol. Microbiol. 2010, 75, 107-121. [CrossRef]

40. Nesbitt, N.M.; Yang, X.; Fontán, P.; Kolesnikova, I.; Smith, I.; Sampson, N.S.; Dubnau, E. A thiolase of Mycobacterium tuberculosis is required for virulence and production of androstenedione and androstadienedione from cholesterol. Infect. Immun. 2010, 78, 275-282. [CrossRef]

41. Yam, K.C.; D’Angelo, I.; Kalscheuer, R.; Zhu, H.; Wang, J.X.; Snieckus, V.; Ly, L.H.; Converse, P.J.; Jacobs, W.R.; Strynadka, N.; et al. Studies of a ring-cleaving dioxygenase illuminate the role of cholesterol metabolism in the pathogenesis of Mycobacterium tuberculosis. PLoS Pathog. 2009, 5, e1000344. [CrossRef]

42. VanderVen, B.C.; Fahey, R.J.; Lee, W.; Liu, Y.; Abramovitch, R.B.; Memmott, C.; Crowe, A.M.; Eltis, L.D.; Perola, E.; Deininger, D.D.; et al. Novel Inhibitors of Cholesterol Degradation in Mycobacterium tuberculosis Reveal How the Bacterium's Metabolism Is Constrained by the Intracellular Environment. PLoS Pathog. 2015, 11, e1004679. [CrossRef] [PubMed]

43. Fineran, P.; Lloyd-Evans, E.; Lack, N.A.; Platt, N.; Davis, L.C.; Morgan, A.J.; Höglinger, D.; Tatituri, R.V.V.; Clark, S.; Williams, I.M.; et al. Pathogenic mycobacteria achieve cellular persistence by inhibiting the Niemann-Pick Type C disease cellular pathway. Wellcome Open Res. 2016, 1, 18. [CrossRef] [PubMed]

44. Billig, S.; Schneefeld, M.; Huber, C.; Grassl, G.A.; Eisenreich, W.; Bange, F.C. Lactate oxidation facilitates growth of Mycobacterium tuberculosis in human macrophages. Sci. Rep. 2017, 7, 1-12. [CrossRef]

45. Serafini, A.; Tan, L.; Horswell, S.; Howell, S.; Greenwood, D.J.; Hunt, D.M.; Phan, M.D.; Schembri, M.; Monteleone, M.; Montague, C.R.; et al. Mycobacterium tuberculosis requires glyoxylate shunt and reverse methylcitrate cycle for lactate and pyruvate metabolism. Mol. Microbiol. 2019, 112, 1284-1307. [CrossRef]

46. Keating, L.A.; Wheeler, P.R.; Mansoor, H.; Inwald, J.K.; Dale, J.; Hewinson, R.G.; Gordon, S.V. The pyruvate requirement of some members of the Mycobacterium tuberculosis complex is due to an inactive pyruvate kinase: Implications for in vivo growth. Mol. Microbiol. 2005, 56, 163-174. [CrossRef] [PubMed]

47. Speer, A.; Sun, J.; Danilchanka, O.; Meikle, V.; Rowland, J.L.; Walter, K.; Buck, B.R.; Pavlenok, M.; Hölscher, C.; Ehrt, S.; et al. Surface hydrolysis of sphingomyelin by the outer membrane protein Rv0888 supports replication of Mycobacterium tuberculosis in macrophages. Mol. Microbiol. 2015, 97, 881-897. [CrossRef] [PubMed]

48. Van der Wel, N.; Hava, D.; Houben, D.; Fluitsma, D.; van Zon, M.; Pierson, J.; Brenner, M.; Peters, P.J. M. tuberculosis and M. leprae translocate from the phagolysosome to the cytosol in myeloid cells. Cell 2007, 129, 1287-1298. [CrossRef]

49. Simeone, R.; Bobard, A.; Lippmann, J.; Bitter, W.; Majlessi, L.; Brosch, R.; Enninga, J. Phagosomal Rupture by Mycobacterium tuberculosis Results in Toxicity and Host Cell Death. PLoS Pathog. 2012, 8, e1002507. [CrossRef]

50. Simeone, J.C.; Ward, A.J.; Rotella, P.; Collins, J.; Windisch, R. An evaluation of variation in published estimates of schizophrenia prevalence from 1990-2013: A systematic literature review. BMC Psychiatry 2015, 15, 193. [CrossRef]

51. Betts, J.C.; Lukey, P.T.; Robb, L.C.; McAdam, R.A.; Duncan, K. Evaluation of a nutrient starvation model of Mycobacterium tuberculosis persistence by gene and protein expression profiling. Mol. Microbiol. 2002, 43, 717-731. [CrossRef]

52. Wayne, L.G.; Hayes, L.G. An in vitro model for sequential study of shiftdown of Mycobacterium tuberculosis through two stages of nonreplicating persistence. Infect. Immun. 1996, 64, 2062-2069. [CrossRef] [PubMed]

53. Rao, S.P.S.; Alonso, S.; Rand, L.; Dick, T.; Pethe, K. The protonmotive force is required for maintaining ATP homeostasis and viability of hypoxic, nonreplicating Mycobacterium tuberculosis. Proc. Natl. Acad. Sci. USA 2008, 105, 11945-11950. [CrossRef] [PubMed]

54. Singh, A.; Guidry, L.; Narasimhulu, K.V.; Mai, D.; Trombley, J.; Redding, K.E.; Giles, G.I.; Lancaster, J.R., Jr.; Steyn, A.J. Mycobacterium tuberculosis WhiB3 responds to $\mathrm{O} 2$ and nitric oxide via its [4Fe-4S] cluster and is essential for nutrient starvation survival. Proc. Natl. Acad. Sci. USA 2007, 104, 11562-11567. [CrossRef] [PubMed]

55. Rustad, T.R.; Harrell, M.I.; Liao, R.; Sherman, D.R. The enduring hypoxic response of Mycobacterium tuberculosis. PLoS ONE 2008, 3, e1502. [CrossRef]

56. Leistikow, R.L.; Morton, R.A.; Bartek, I.L.; Frimpong, I.; Wagner, K.; Voskuil, M.I. The Mycobacterium tuberculosis DosR Regulon Assists in Metabolic Homeostasis and Enables Rapid Recovery from Nonrespiring Dormancy. J. Bacteriol. $2010,192,1662$. [CrossRef]

57. Schubert, O.T.; Ludwig, C.; Kogadeeva, M.; Zimmermann, M.; Rosenberger, G.; Gengenbacher, M.; Gillet, L.C.; Collins, B.C.; Röst, H.L.; Kaufmann, S.H.; et al. Absolute Proteome Composition and Dynamics during Dormancy and Resuscitation of Mycobacterium tuberculosis. Cell Host Microbe 2015, 18, 96-108. [CrossRef]

58. Peterson, E.J.R.; Abidi, A.A.; Arrieta-Ortiz, M.L.; Aguilar, B.; Yurkovich, J.T.; Kaur, A.; Pan, M.; Srinivas, V.; Shmulevich, I.; Baliga, N.S. Intricate Genetic Programs Controlling Dormancy in Mycobacterium tuberculosis. Cell Rep. 2020, 31, 107577. [CrossRef]

59. Tian, J.; Bryk, R.; Itoh, M.; Suematsu, M.; Nathan, C. Variant tricarboxylic acid cycle in Mycobacterium tuberculosis: Identification of alpha-ketoglutarate decarboxylase. Proc. Natl. Acad. Sci. USA 2005, 102, 10670-10675. [CrossRef]

60. Cole, S.T.; Brosch, R.; Parkhill, J.; Garnier, T.; Churcher, C.; Harris, D.; Gordon, S.V.; Eiglmeier, K.; Gas, S.; Barry, C.E., 3rd; et al. Deciphering the biology of Mycobacterium tuberculosis from the complete genome sequence. Nature 1998, 393, 537-544. [CrossRef] 
61. Tian, J.; Bryk, R.; Shi, S.; Erdjument-Bromage, H.; Tempst, P.; Nathan, C. Mycobacterium tuberculosis appears to lack alphaketoglutarate dehydrogenase and encodes pyruvate dehydrogenase in widely separated genes. Mol. Microbiol. 2005, 57, 859-868. [CrossRef]

62. Gest, H. Evolution of the citric acid cycle and respiratory energy conversion in prokaryotes. FEMS Microbiol. Lett. 1981, 12, 209-215. [CrossRef]

63. Eoh, H.; Rhee, K.Y. Multifunctional essentiality of succinate metabolism in adaptation to hypoxia in Mycobacterium tuberculosis. Proc. Natl. Acad. Sci. USA 2013, 110, 6554-6559. [CrossRef] [PubMed]

64. Muñoz-Elías, E.J.; McKinney, J.D. Carbon metabolism of intracellular bacteria. Cell. Microbiol. 2006, 8, 10-22. [CrossRef] [PubMed]

65. Nandakumar, M.; Nathan, C.; Rhee, K.Y. Isocitrate lyase mediates broad antibiotic tolerance in Mycobacterium tuberculosis. Nat. Commun. 2014, 5, 1-10. [CrossRef] [PubMed]

66. Watanabe, S.; Zimmermann, M.; Goodwin, M.B.; Sauer, U.; Barry, C.E.; Boshoff, H.I. Fumarate reductase activity maintains an energized membrane in anaerobic Mycobacterium tuberculosis. PLoS Pathog. 2011, 7, e1002287. [CrossRef] [PubMed]

67. Larrouy-Maumus, G.; Marino, L.B.; Madduri, A.V.R.; Ragan, T.J.; Hunt, D.M.; Bassano, L.; Gutierrez, M.G.; Moody, D.B.; Pavan, F.R.; De Carvalho, L.P.S. Cell-envelope remodeling as a determinant of phenotypic antibacterial tolerance in Mycobacterium tuberculosis. ACS Infect. Dis. 2016, 2, 352-360. [CrossRef] [PubMed]

68. Eoh, H.; Wang, Z.; Layre, E.; Rath, P.; Morris, R.; Branch Moody, D.; Rhee, K.Y. Metabolic anticipation in Mycobacterium tuberculosis. Nat. Microbiol. 2017, 2, 1-7. [CrossRef]

69. Zhong, W.; Guo, J.; Cui, L.; Chionh, Y.H.; Li, K.; El Sahili, A.; Cai, Q.; Yuan, M.; Michels, P.A.M.; Fothergill-Gilmore, L.A.; et al. Pyruvate Kinase Regulates the Pentose-Phosphate Pathway in Response to Hypoxia in Mycobacterium tuberculosis. J. Mol. Biol. 2019, 431, 3690-3705. [CrossRef]

70. Baker, J.J.; Johnson, B.K.; Abramovitch, R.B. Slow growth of Mycobacterium tuberculosis at acidic pH is regulated by phoPR and host-associated carbon sources. Mol. Microbiol. 2014, 94, 56-69. [CrossRef]

71. Rizvi, A.; Shankar, A.; Chatterjee, A.; More, T.H.; Bose, T.; Dutta, A.; Balakrishnan, K.; Madugulla, L.; Rapole, S.; Mande, S.S.C.S.S.; et al. Rewiring of Metabolic Network in Mycobacterium tuberculosis During Adaptation to Different Stresses. Front. Microbiol. 2019, 10, 2417. [CrossRef]

72. Kalscheuer, R.; Koliwer-Brandl, H. Genetics of Mycobacterial Trehalose Metabolism. Microbiol. Spectr. 2014, 2, 361-375. [CrossRef] [PubMed]

73. Elbein, A.D.; Pan, Y.T.; Pastuszak, I.; Carroll, D. New insights on trehalose: A multifunctional molecule. Glycobiology 2003, 13, 17R-27R. [CrossRef] [PubMed]

74. Lee, J.J.; Lee, S.K.; Song, N.; Nathan, T.O.; Swarts, B.M.; Eum, S.Y.; Ehrt, S.; Cho, S.N.; Eoh, H. Transient drug-tolerance and permanent drug-resistance rely on the trehalose-catalytic shift in Mycobacterium tuberculosis. Nat. Commun. 2019, 10, 1-12. [CrossRef] [PubMed]

75. Galagan, J.E.; Minch, K.; Peterson, M.; Lyubetskaya, A.; Azizi, E.; Sweet, L.; Gomes, A.; Rustad, T.; Dolganov, G.; Glotova, I.; et al. The Mycobacterium tuberculosis regulatory network and hypoxia. Nature 2013, 499, 178-183. [CrossRef] [PubMed]

76. Baek, S.-H.; Li, A.H.; Sassetti, C.M. Metabolic regulation of mycobacterial growth and antibiotic sensitivity. PLoS Biol. 2011, 9, e1001065. [CrossRef]

77. Cunningham, A.F.; Spreadbury, C.L. Mycobacterial stationary phase induced by low oxygen tension: Cell wall thickening and localization of the 16-kilodalton alpha-crystallin homolog. J. Bacteriol. 1998, 180, 801-808. [CrossRef]

78. Fahy, E.; Cotter, D.; Sud, M.; Subramaniam, S. Lipid classification, structures and tools. Biochim. Biophys. Acta 2011, 1811, 637-647. [CrossRef]

79. Sartain, M.J.; Dick, D.L.; Rithner, C.D.; Crick, D.C.; Belisle, J.T. Lipidomic analyses of Mycobacterium tuberculosis based on accurate mass measurements and the novel "Mtb LipidDB". J. Lipid Res. 2011, 52, 861-872. [CrossRef]

80. Rodríguez, J.G.; Hernández, A.C.; Helguera-Repetto, C.; Aguilar Ayala, D.; Guadarrama-Medina, R.; Anzóla, J.M.; Bustos, J.R.; Zambrano, M.M.; González-y-Merchand, J.; García, M.J.; et al. Global Adaptation to a Lipid Environment Triggers the Dormancy-Related Phenotype of Mycobacterium tuberculosis. mBio 2014, 5, e01125-01114. [CrossRef]

81. Shleeva, M.; Goncharenko, A.; Kudykina, Y.; Young, D.; Young, M.; Kaprelyants, A. Cyclic Amp-Dependent Resuscitation of Dormant Mycobacteria by Exogenous Free Fatty Acids. PLoS ONE 2013, 8, e82914. [CrossRef]

82. McGillivray, A.; Golden, N.A.; Kaushal, D. The Mycobacterium tuberculosis Clp gene regulator is required for in vitro reactivation from hypoxia-induced dormancy. J. Biol. Chem. 2015, 290, 2351-2367. [CrossRef] [PubMed]

83. Peterson, E., Jr.; Bailo, R.; Rothchild, A.C.; Arrieta-Ortiz, M.L.; Kaur, A.; Pan, M.; Mai, D.; Abidi, A.A.; Cooper, C.; Aderem, A.; et al. Path-seq identifies an essential mycolate remodeling program for mycobacterial host adaptation. Mol. Syst. Biol. 2019, 15, e8584. [CrossRef] [PubMed]

84. Deb, C.; Daniel, J.; Sirakova, T.D.; Abomoelak, B.; Dubey, V.S.; Kolattukudy, P.E. A novel lipase belonging to the hormone-sensitive lipase family induced under starvation to utilize stored triacylglycerol in Mycobacterium tuberculosis. J. Biol. Chem. 2006, 281, 3866-3875. [CrossRef] [PubMed]

85. Cotes, K.; Bakala N'goma, J.C.; Dhouib, R.; Douchet, I.; Maurin, D.; Carriere, F.; Canaan, S. Lipolytic enzymes in Mycobacterium tuberculosis. Appl. Microbiol. Biotechnol. 2008, 78, 741-749. [CrossRef]

86. Singh, G.; Singh, G.; Jadeja, D.; Kaur, J. Lipid hydrolizing enzymes in virulence: Mycobacterium tuberculosis as a model system. Crit. Rev. Microbiol. 2010, 36, 259-269. [CrossRef] 
87. Santucci, P.; Diomandé, S.; Poncin, I.; Alibaud, L.; Viljoen, A.; Kremer, L.; de Chastellier, C.; Canaan, S. Delineating the Physiological Roles of the PE and Catalytic Domains of LipY in Lipid Consumption in Mycobacterium-Infected Foamy Macrophages. Infect. Immun. 2018, 86, e00394-00318. [CrossRef]

88. Deb, C.; Lee, C.-M.; Dubey, V.S.; Daniel, J.; Abomoelak, B.; Sirakova, T.D.; Pawar, S.; Rogers, L.; Kolattukudy, P.E. A Novel In Vitro Multiple-Stress Dormancy Model for Mycobacterium tuberculosis Generates a Lipid-Loaded, Drug-Tolerant, Dormant Pathogen. PLoS ONE 2009, 4, e6077. [CrossRef]

89. Low, K.L.; Rao, P.S.S.; Shui, G.; Bendt, A.K.; Pethe, K.; Dick, T.; Wenk, M.R. Triacylglycerol Utilization Is Required for Regrowth of In Vitro Hypoxic Nonreplicating Mycobacterium bovis Bacillus Calmette-Guerin. J. Bacteriol. 2009, 191, 5037. [CrossRef]

90. Sirakova, T.D.; Dubey, V.S.; Deb, C.; Daniel, J.; Korotkova, T.A.; Abomoelak, B.; Kolattukudy, P.E. Identification of a diacylglycerol acyltransferase gene involved in accumulation of triacylglycerol in Mycobacterium tuberculosis under stress. Microbiol. Read. Engl. 2006, 152, 2717-2725. [CrossRef]

91. Garton, N.J.; Waddell, S.J.; Sherratt, A.L.; Lee, S.M.; Smith, R.J.; Senner, C.; Hinds, J.; Rajakumar, K.; Adegbola, R.A.; Besra, G.S.; et al. Cytological and transcript analyses reveal fat and lazy persister-like bacilli in tuberculous sputum. PLoS Medicine 2008, 5, 634-645. [CrossRef]

92. Daniel, J.; Sirakova, T.; Kolattukudy, P. An acyl-CoA synthetase in Mycobacterium tuberculosis involved in triacylglycerol accumulation during dormancy. PLoS ONE 2014, 9, e114877. [CrossRef] [PubMed]

93. Daniel, J.; Maamar, H.; Deb, C.; Sirakova, T.D.; Kolattukudy, P.E. Mycobacterium tuberculosis uses host triacylglycerol to accumulate lipid droplets and acquires a dormancy-like phenotype in lipid-loaded macrophages. PLoS Pathog. 2011, 7, e1002093. [CrossRef] [PubMed]

94. Caire-Brändli, I.; Papadopoulos, A.; Malaga, W.; Marais, D.; Canaan, S.; Thilo, L.; de Chastellier, C. Reversible Lipid Accumulation and Associated Division Arrest of Mycobacterium avium in Lipoprotein-Induced Foamy Macrophages May Resemble Key Events during Latency and Reactivation of Tuberculosis. Infect. Immun. 2014, 82, 476. [CrossRef] [PubMed]

95. Barisch, C.; Soldati, T. Mycobacterium marinum Degrades Both Triacylglycerols and Phospholipids from Its Dictyostelium Host to Synthesise Its Own Triacylglycerols and Generate Lipid Inclusions. PLoS Pathog. 2017, 13, e1006095. [CrossRef]

96. Alvarez, H.M.; Steinbuchel, A. Triacylglycerols in prokaryotic microorganisms. Appl. Microbiol. Biotechnol. 2002, 60, 367-376. [CrossRef]

97. Banoub, J.H.; Aneed, A.E.; Cohen, A.M.; Joly, N. Structural investigation of bacterial lipopolysaccharides by mass spectrometry and tandem mass spectrometry. Mass Spectrom. Rev. 2010, 29, 606-650. [CrossRef]

98. Sirakova, T.D.; Thirumala, A.K.; Dubey, V.S.; Sprecher, H.; Kolattukudy, P.E. The Mycobacterium tuberculosis pks2 Gene Encodes the Synthase for the Hepta- and Octamethyl-branched Fatty Acids Required for Sulfolipid Synthesis. J. Biol. Chem. 2001, 276, 16833-16839. [CrossRef]

99. Foo, C.S.-Y.; Pethe, K.; Lupien, A. Oxidative Phosphorylation-An Update on a New, Essential Target Space for Drug Discovery in Mycobacterium tuberculosis. Appl. Sci. 2020, 10, 2339. [CrossRef]

100. Mdluli, K.; Kaneko, T.; Upton, A. The tuberculosis drug discovery and development pipeline and emerging drug targets. Cold Spring Harb. Perspect. Med. 2015, 5, a021154. [CrossRef]

101. North, E.J.; Jackson, M.; Lee, R.E. New approaches to target the mycolic acid biosynthesis pathway for the development of tuberculosis therapeutics. Curr. Pharm. Des. 2014, 20, 4357-4378. [CrossRef]

102. Bald, D.; Villellas, C.; Lu, P.; Koul, A. Targeting Energy Metabolism in Mycobacterium tuberculosis, a New Paradigm in Antimycobacterial Drug Discovery. mBio 2017, 8, e00272-17. [CrossRef] [PubMed]

103. Förster, A.H.; Gescher, J. Metabolic Engineering of Escherichia coli for Production of Mixed-Acid Fermentation End Products. Front. Bioeng. Biotechnol. 2014, 2, 16. [PubMed]

104. Clark, D.P. The fermentation pathways of Escherichia coli. FEMS Microbiol. Lett. 1989, 63, 223-234. [CrossRef]

105. Dhandayuthapani, S.; Zhang, Y.; Mudd, M.H.; Deretic, V.; Cook, G.M.; Hards, K.; Dunn, E.; Heikal, A.; Nakatani, Y.; Greening, C.; et al. Oxidative Phosphorylation as a Target Space for Tuberculosis: Success, Caution, and Future Directions. Microbiol. Spectr. 2017, 5, 295-316. [CrossRef]

106. Pym, A.S.; Diacon, A.H.; Tang, S.-J.; Conradie, F.; Danilovits, M.; Chuchottaworn, C.; Vasilyeva, I.; Andries, K.; Bakare, N.; De Marez, T.; et al. Bedaquiline in the treatment of multidrug- and extensively drug-resistant tuberculosis. Eur. Respir. J. 2016, 47, 564-574. [CrossRef]

107. Andries, K.; Verhasselt, P.; Guillemont, J.; Göhlmann, H.W.H.; Neefs, J.-M.; Winkler, H.; Van Gestel, J.; Timmerman, P.; Zhu, M.; Lee, E.; et al. A Diarylquinoline Drug Active on the ATP Synthase of Mycobacterium tuberculosis. Science 2005, 307, $223-227$. [CrossRef]

108. Cox, E.; Laessig, K. FDA approval of bedaquiline-the benefit-risk balance for drug-resistant tuberculosis. N. Engl. J. Med. 2014, 371, 689-691. [CrossRef]

109. Koul, A.; Vranckx, L.; Dendouga, N.; Balemans, W.; Van den Wyngaert, I.; Vergauwen, K.; Göhlmann, H.W.; Willebrords, R.; Poncelet, A.; Guillemont, J.; et al. Diarylquinolines are bactericidal for dormant mycobacteria as a result of disturbed ATP homeostasis. J. Biol. Chem. 2008, 283, 25273-25280. [CrossRef]

110. Harbut, M.B.; Yang, B.; Liu, R.; Yano, T.; Vilchèze, C.; Cheng, B.; Lockner, J.; Guo, H.; Yu, C.; Franzblau, S.G.; et al. Small Molecules Targeting Mycobacterium tuberculosis Type II NADH Dehydrogenase Exhibit Antimycobacterial Activity. Angew. Chem. 2018, 57, 3478-3482. [CrossRef] 
111. Murugesan, D.; Ray, P.C.; Bayliss, T.; Prosser, G.A.; Harrison, J.R.; Green, K.; Soares de Melo, C.; Feng, T.-S.; Street, L.J.; Chibale, K.; et al. 2-Mercapto-Quinazolinones as Inhibitors of Type II NADH Dehydrogenase and Mycobacterium tuberculosis: StructureActivity Relationships, Mechanism of Action and Absorption, Distribution, Metabolism, and Excretion Characterization. ACS Infect. Dis. 2018, 4, 954-969. [CrossRef]

112. Kurosu, M.; Crick, D.C. MenA is a promising drug target for developing novel lead molecules to combat Mycobacterium tuberculosis. Med. Chem. 2009, 5, 197-207. [CrossRef] [PubMed]

113. Sukheja, P.; Kumar, P.; Mittal, N.; Li, S.-G.; Singleton, E.; Russo, R.; Perryman, A.L.; Shrestha, R.; Awasthi, D.; Husain, S.; et al. A Novel Small-Molecule Inhibitor of the Mycobacterium tuberculosis Demethylmenaquinone Methyltransferase MenG Is Bactericidal to Both Growing and Nutritionally Deprived Persister Cells. mBio 2017, 8, e02022-02016. [CrossRef] [PubMed]

114. Cleghorn, L.A.T.; Ray, P.C.; Odingo, J.; Kumar, A.; Wescott, H.; Korkegian, A.; Masquelin, T.; Lopez Moure, A.; Wilson, C.; Davis, S.; et al. Identification of Morpholino Thiophenes as Novel Mycobacterium tuberculosis Inhibitors, Targeting QcrB. J. Med. Chem. 2018, 61, 6592-6608. [CrossRef] [PubMed]

115. Chandrasekera, N.S.; Berube, B.J.; Shetye, G.; Chettiar, S.; O’Malley, T.; Manning, A.; Flint, L.; Awasthi, D.; Ioerger, T.R.; Sacchettini, J.; et al. Improved Phenoxyalkylbenzimidazoles with Activity against Mycobacterium tuberculosis Appear to Target QcrB. ACS Infect. Dis. 2017, 3, 898-916. [CrossRef] [PubMed]

116. de Jager, V.R.; Dawson, R.; van Niekerk, C.; Hutchings, J.; Kim, J.; Vanker, N.; van der Merwe, L.; Choi, J.; Nam, K.; Diacon, A.H. Telacebec (Q203), a New Antituberculosis Agent. N. Engl. J. Med. 2020, 382, 1280-1281. [CrossRef]

117. Koul, A.; Vranckx, L.; Dhar, N.; Göhlmann, H.W.H.; Özdemir, E.; Neefs, J.-M.; Schulz, M.; Lu, P.; Mørtz, E.; McKinney, J.D.; et al. Delayed bactericidal response of Mycobacterium tuberculosis to bedaquiline involves remodelling of bacterial metabolism. Nat. Commun. 2014, 5, 3369. [CrossRef]

118. Greenwood, D.J.; Dos Santos, M.S.; Huang, S.; Russell, M.R.G.; Collinson, L.M.; MacRae, J.I.; West, A.; Jiang, H.; Gutierrez, M.G. Subcellular antibiotic visualization reveals a dynamic drug reservoir in infected macrophages. Science 2019, 364, 1279. [CrossRef]

119. Pethe, K.; Bifani, P.; Jang, J.; Kang, S.; Park, S.; Ahn, S.; Jiricek, J.; Jung, J.; Jeon, H.K.; Cechetto, J.; et al. Discovery of Q203, a potent clinical candidate for the treatment of tuberculosis. Nat. Med. 2013, 19, 1157-1160. [CrossRef]

120. Kalia, N.P.; Shi Lee, B.; Ab Rahman, N.B.; Moraski, G.C.; Miller, M.J.; Pethe, K. Carbon metabolism modulates the efficacy of drugs targeting the cytochrome bc 1:aa 3 in Mycobacterium tuberculosis. Sci. Rep. 2019, 9, 1-9. [CrossRef]

121. Huang, L.; Kushner, N.L.; Theriault, M.E.; Pisu, D.; Tan, S.; McNamara, C.W.; Petrassi, H.M.; Russell, D.G.; Brown, A.C. The Deconstructed Granuloma: A Complex High-Throughput Drug Screening Platform for the Discovery of Host-Directed Therapeutics Against Tuberculosis. Front. Cell. Infect. Microbiol. 2018, 8, 275. [CrossRef]

122. Isoniazid trials. Lancet 1952, 2, 471-472. [CrossRef]

123. Clark, C.M.; Elmendorf, D.F., Jr.; Cawthon, W.U.; Muschenheim, C.; McDermott, W. Isoniazid (isonicotinic acid hydrazide) in the treatment of miliary and meningeal tuberculosis. Am. Rev. Tuberc. 1952, 66, 391-415. [CrossRef] [PubMed]

124. Winder, F.G.; Collins, P.; Rooney, S.A. Effects of isoniazid on mycolic acid synthesis in Mycobacterium tuberculosis and on its cell envelope. Biochem. J. 1970, 117, 27P. [CrossRef] [PubMed]

125. Banerjee, A.; Dubnau, E.; Quemard, A.; Balasubramanian, V.; Um, K.S.; Wilson, T.; Collins, D.; de Lisle, G.; Jacobs, W.R., Jr. inhA, a gene encoding a target for isoniazid and ethionamide in Mycobacterium tuberculosis. Science 1994, 263, 227-230. [CrossRef]

126. Phetsuksiri, B.; Jackson, M.; Scherman, H.; McNeil, M.; Besra, G.S.; Baulard, A.R.; Slayden, R.A.; DeBarber, A.E.; Barry, C.E., 3rd; Baird, M.S.; et al. Unique mechanism of action of the thiourea drug isoxyl on Mycobacterium tuberculosis. J. Biol. Chem. 2003, 278, 53123-53130. [CrossRef]

127. Grzegorzewicz, A.E.; Kordulakova, J.; Jones, V.; Born, S.E.; Belardinelli, J.M.; Vaquie, A.; Gundi, V.A.; Madacki, J.; Slama, N.; Laval, F.; et al. A common mechanism of inhibition of the Mycobacterium tuberculosis mycolic acid biosynthetic pathway by isoxyl and thiacetazone. J. Biol. Chem. 2012, 287, 38434-38441. [CrossRef]

128. Baran, M.; Grimes, K.D.; Sibbald, P.A.; Fu, P.; Boshoff, H.I.M.; Wilson, D.J.; Aldrich, C.C. Development of small-molecule inhibitors of fatty acyl-AMP and fatty acyl-CoA ligases in Mycobacterium tuberculosis. Eur. J. Med. Chem. 2020, 201, 112408. [CrossRef]

129. Mohanty, D.; Sankaranarayanan, R.; Gokhale, R.S. Fatty acyl-AMP ligases and polyketide synthases are unique enzymes of lipid biosynthetic machinery in Mycobacterium tuberculosis. Tuberculosis 2011, 91, 448-455. [CrossRef]

130. Sharma, V.; Sharma, S.; zu Bentrup, K.H.; McKinney, J.D.; Russell, D.G.; Jacobs, W.R.; Sacchettini, J.C. Structure of isocitrate lyase, a persistence factor of Mycobacterium tuberculosis. Nat. Struct. Biol. 2000, 7, 663-668. [CrossRef]

131. Krátký, M.; Vinšová, J.; Novotná, E.; Mandíková, J.; Wsól, V.; Trejtnar, F.; Ulmann, V.; Stolaříková, J.; Fernandes, S.; Bhat, S.; et al. Salicylanilide derivatives block Mycobacterium tuberculosis through inhibition of isocitrate lyase and methionine aminopeptidase. Tuberculosis 2012, 92, 434-439. [CrossRef]

132. Sriram, D.; Aubry, A.; Yogeeswari, P.; Fisher, L.M. Gatifloxacin derivatives: Synthesis, antimycobacterial activities, and inhibition of Mycobacterium tuberculosis DNA gyrase. Bioorg. Med. Chem. Lett. 2006, 16, 2982-2985. [CrossRef] [PubMed]

133. Sriram, D.; Yogeeswari, P.; Vyas, D.R.; Senthilkumar, P.; Bhat, P.; Srividya, M. 5-Nitro-2-furoic acid hydrazones: Design, synthesis and in vitro antimycobacterial evaluation against log and starved phase cultures. Bioorg. Med. Chem. Lett. 2010, 20, 4313-4316. [CrossRef] [PubMed] 
134. Sriram, D.; Yogeeswari, P.; Senthilkumar, P.; Naidu, G.; Bhat, P. 5-Nitro-2,6-dioxohexahydro-4-pyrimidinecarboxamides: Synthesis, in vitro antimycobacterial activity, cytotoxicity, and isocitrate lyase inhibition studies. J. Enzym. Inhib. Med. Chem. 2010, 25, 765-772. [CrossRef]

135. Tahlan, K.; Wilson, R.; Kastrinsky, D.B.; Arora, K.; Nair, V.; Fischer, E.; Barnes, S.W.; Walker, J.R.; Alland, D.; Barry, C.E.; et al. SQ109 Targets MmpL3, a Membrane Transporter of Trehalose Monomycolate Involved in Mycolic Acid Donation to the Cell Wall Core of Mycobacterium tuberculosis. Antimicrob. Agents Chemother. 2012, 56, 1797. [CrossRef] [PubMed]

136. Xu, Z.; Meshcheryakov, V.A.; Poce, G.; Chng, S.-S. MmpL3 is the flippase for mycolic acids in mycobacteria. Proc. Natl. Acad. Sci. USA 2017, 114, 7993-7998. [CrossRef]

137. Borisov, S.; Bogorodskaya, E.; Volchenkov, G.; Kulchavenya, E.; Maryandyshev, A.; Skornyakov, S.; Talibov, O.; Tikhonov, A.; Vasilyeva, I. Efficiency and safety of chemotherapy regimen with SQ109 in those suffering from multiple drug resistant tuberculosis. Tuberc. Lung. Dis. 2018, 96, 6-18. [CrossRef]

138. Martinot, A.J.; Farrow, M.; Bai, L.; Layre, E.; Cheng, T.-Y.; Tsai, J.H.; Iqbal, J.; Annand, J.W.; Sullivan, Z.A.; Hussain, M.M.; et al. Mycobacterial Metabolic Syndrome: LprG and Rv1410 Regulate Triacylglyceride Levels, Growth Rate and Virulence in Mycobacterium tuberculosis. PLoS Pathog. 2016, 12, e1005351. [CrossRef]

139. Gaur, R.L.; Ren, K.; Blumenthal, A.; Bhamidi, S.; Gibbs, S.; Jackson, M.; Zare, R.N.; Ehrt, S.; Ernst, J.D.; Banaei, N. LprG-Mediated Surface Expression of Lipoarabinomannan Is Essential for Virulence of Mycobacterium tuberculosis. PLoS Pathog. 2014, 10, e1004376. [CrossRef]

140. Pisu, D.; Huang, L.; Grenier, J.K.; Russell, D.G. Dual RNA-Seq of Mtb-Infected Macrophages In Vivo Reveals Ontologically Distinct Host-Pathogen Interactions. Cell Rep. 2020, 30, 335.e334-350.e334. [CrossRef]

141. Vrieling, F.; Kostidis, S.; Spaink, H.P.; Haks, M.C.; Mayboroda, O.A.; Ottenhoff, T.H.M.; Joosten, S.A. Analyzing the impact of Mycobacterium tuberculosis infection on primary human macrophages by combined exploratory and targeted metabolomics. Sci. Rep. 2020, 10, 7085. [CrossRef]

142. Beste, D.J.V.; Bonde, B.; Hawkins, N.; Ward, J.L.; Beale, M.H.; Noack, S.; Nöh, K.; Kruger, N.J.; Ratcliffe, R.G.; McFadden, J. 13C Metabolic Flux Analysis Identifies an Unusual Route for Pyruvate Dissimilation in Mycobacteria which Requires Isocitrate Lyase and Carbon Dioxide Fixation. PLoS Pathog. 2011, 7, e1002091. [CrossRef]

143. Carninci, P.; Kvam, C.; Kitamura, A.; Ohsumi, T.; Okazaki, Y.; Itoh, M.; Kamiya, M.; Shibata, K.; Sasaki, N.; Izawa, M.; et al. High-efficiency full-length cDNA cloning by biotinylated CAP trapper. Genomics 1996, 37, 327-336. [CrossRef] [PubMed]

144. Duffy, F.J.; Weiner, J., 3rd; Hansen, S.; Tabb, D.L.; Suliman, S.; Thompson, E.; Maertzdorf, J.; Shankar, S.; Tromp, G.; Parida, S.; et al. Immunometabolic Signatures Predict Risk of Progression to Active Tuberculosis and Disease Outcome. Front Immunol. 2019, 10, 527. [CrossRef]

145. Crick, P.J.; Guan, X.L. Lipid metabolism in mycobacteria-Insights using mass spectrometry-based lipidomics. Biochim. Biophys. Acta 2016, 1861, 60-67. [CrossRef] [PubMed]

146. Zimmermann, M.; Kuehne, A.; Boshoff, H.I.; Barry, C.E., 3rd; Zamboni, N.; Sauer, U. Dynamic exometabolome analysis reveals active metabolic pathways in non-replicating mycobacteria. Env. Microbiol. 2015, 17, 4802-4815. [CrossRef] [PubMed]

147. Layre, E.; Sweet, L.; Hong, S.; Madigan, C.A.; Desjardins, D.; Young, D.C.; Cheng, T.-Y.; Annand, J.W.; Kim, K.; Shamputa, I.C.; et al. A comparative lipidomics platform for chemotaxonomic analysis of Mycobacterium tuberculosis. Chem. Biol. 2011, 18, 1537-1549. [CrossRef]

148. Emwas, A.H. The strengths and weaknesses of NMR spectroscopy and mass spectrometry with particular focus on metabolomics research. Methods Mol. Biol. 2015, 1277, 161-193. [CrossRef]

149. Fernández-García, M.; Rey-Stolle, F.; Boccard, J.; Reddy, V.P.; García, A.; Cumming, B.M.; Steyn, A.J.C.; Rudaz, S.; Barbas, C. Comprehensive Examination of the Mouse Lung Metabolome Following Mycobacterium tuberculosis Infection Using a Multiplatform Mass Spectrometry Approach. J. Proteome Res. 2020, 19, 2053-2070. [CrossRef]

150. Zampieri, M.; Szappanos, B.; Buchieri, M.V.; Trauner, A.; Piazza, I.; Picotti, P.; Gagneux, S.; Borrell, S.; Gicquel, B.; Lelievre, J.; et al. High-throughput metabolomic analysis predicts mode of action of uncharacterized antimicrobial compounds. Sci. Transl. Med. 2018, 10, eaal3973. [CrossRef]

151. Diaz, C.; Perez Del Palacio, J.; Valero-Guillen, P.L.; Mena Garcia, P.; Perez, I.; Vicente, F.; Martin, C.; Genilloud, O.; Sanchez Pozo, A.; Gonzalo-Asensio, J. Comparative Metabolomics between Mycobacterium tuberculosis and the MTBVAC Vaccine Candidate. ACS Infect. Dis. 2019, 5, 1317-1326. [CrossRef]

152. Drapal, M.; Fraser, P.D. Metabolite Profiling: A Tool for the Biochemical Characterisation of Mycobacterium sp. Microorganisms 2019, 7, 148. [CrossRef] [PubMed]

153. Avraham, R.; Haseley, N.; Brown, D.; Penaranda, C.; Jijon, H.B.; Trombetta, J.J.; Satija, R.; Shalek, A.K.; Xavier, R.J.; Regev, A.; et al. Pathogen Cell-to-Cell Variability Drives Heterogeneity in Host Immune Responses. Cell 2015, 162, 1309-1321. [CrossRef] [PubMed]

154. Saliba, A.-E.; Li, L.; Westermann, A.J.; Appenzeller, S.; Stapels, D.A.C.; Schulte, L.N.; Helaine, S.; Vogel, J. Single-cell RNA-seq ties macrophage polarization to growth rate of intracellular Salmonella. Nat. Microbiol. 2016, 2, 16206. [CrossRef]

155. Maglica, Ž.; Özdemir, E.; McKinney, J.D. Single-Cell Tracking Reveals Antibiotic-Induced Changes in Mycobacterial Energy Metabolism. mBio 2015, 6, e02236-02214. [CrossRef]

156. Wakamoto, Y.; Dhar, N.; Chait, R.; Schneider, K.; Signorino-Gelo, F.; Leibler, S.; McKinney, J.D. Dynamic Persistence of AntibioticStressed Mycobacteria. Science 2013, 339, 91-95. [CrossRef] [PubMed] 
157. Kirschman, J.C.; Ogongo, P.; Ernst, J.; Altin, J. Single cell transcriptomics of the T cell response to Mycobacterium tuberculosis reveals phenotypic diversity within and between infected individuals. J. Immunol. 2020, 204, 225.221.

158. Cai, Y.; Dai, Y.; Wang, Y.; Yang, Q.; Guo, J.; Wei, C.; Chen, W.; Huang, H.; Zhu, J.; Zhang, C.; et al. Single-cell transcriptomics of blood reveals a natural killer cell subset depletion in tuberculosis. EBioMedicine 2020, 53, 102686. [CrossRef]

159. Gagneux, S. Ecology and evolution of Mycobacterium tuberculosis. Nat. Rev. Microbiol. 2018, 16, 202-213. [CrossRef] [PubMed]

160. Tong, J.; Liu, Q.; Wu, J.; Jiang, Y.; Takiff, H.E.; Gao, Q. Mycobacterium tuberculosis strains of the modern Beijing sublineage excessively accumulate triacylglycerols in vitro. Tuberculosis 2020, 120, 101892. [CrossRef]

161. Rose, G.; Cortes, T.; Comas, I.; Coscolla, M.; Gagneux, S.; Young, D.B. Mapping of genotype-phenotype diversity among clinical isolates of Mycobacterium tuberculosis by sequence-based transcriptional profiling. Genome Biol. Evol. 2013, 5, 1849-1862. [CrossRef]

162. Oyas, O.; Borrell, S.; Trauner, A.; Zimmermann, M.; Feldmann, J.; Liphardt, T.; Gagneux, S.; Stelling, J.; Sauer, U.; Zampieri, M. Model-based integration of genomics and metabolomics reveals SNP functionality in Mycobacterium tuberculosis. Proc. Natl. Acad. Sci. USA 2020, 117, 8494-8502. [CrossRef] [PubMed]

163. Portevin, D.; Sukumar, S.; Coscolla, M.; Shui, G.; Li, B.; Guan, X.L.; Bendt, A.K.; Young, D.; Gagneux, S.; Wenk, M.R. Lipidomics and genomics of Mycobacterium tuberculosis reveal lineage-specific trends in mycolic acid biosynthesis. Microbiologyopen 2014, 3, 823-835. [CrossRef] [PubMed]

164. Liu, Y.; Rebollo-Ramirez, S.; Larrouy-Maumus, G. Metabolomics reveals that the cAMP receptor protein regulates nitrogen and peptidoglycan synthesis in Mycobacterium tuberculosis. RSC Adv. 2020, 10, 26212-26219. [CrossRef]

165. Kahramanoglou, C.; Cortes, T.; Matange, N.; Hunt, D.M.; Visweswariah, S.S.; Young, D.B.; Buxton, R.S. Genomic mapping of cAMP receptor protein (CRPMt) in Mycobacterium tuberculosis: Relation to transcriptional start sites and the role of CRPMt as a transcription factor. Nucleic Acids Res. 2014, 42, 8320-8329. [CrossRef]

166. Barrett, T.; Wilhite, S.E.; Ledoux, P.; Evangelista, C.; Kim, I.F.; Tomashevsky, M.; Marshall, K.A.; Phillippy, K.H.; Sherman, P.M.; Holko, M.; et al. NCBI GEO: Archive for functional genomics data sets-update. Nucleic Acids Res. 2013, 41, D991-D995. [CrossRef]

167. Edgar, R.; Domrachev, M.; Lash, A.E. Gene Expression Omnibus: NCBI gene expression and hybridization array data repository. Nucleic Acids Res. 2002, 30, 207-210. [CrossRef]

168. Karp, P.D.; Billington, R.; Caspi, R.; Fulcher, C.A.; Latendresse, M.; Kothari, A.; Keseler, I.M.; Krummenacker, M.; Midford, P.E.; Ong, Q.; et al. The BioCyc collection of microbial genomes and metabolic pathways. Brief. Bioinform. 2019, 20, 1085-1093. [CrossRef]

169. Davis, J.J.; Wattam, A.R.; Aziz, R.K.; Brettin, T.; Butler, R.; Butler, R.M.; Chlenski, P.; Conrad, N.; Dickerman, A.; Dietrich, E.M.; et al. The PATRIC Bioinformatics Resource Center: Expanding data and analysis capabilities. Nucleic Acids Res. 2020, 48, D606-D612. [CrossRef]

170. Kapopoulou, A.; Lew, J.M.; Cole, S.T. The MycoBrowser portal: A comprehensive and manually annotated resource for mycobacterial genomes. Tuberculosis 2011, 91, 8-13. [CrossRef]

171. Haug, K.; Cochrane, K.; Nainala, V.C.; Williams, M.; Chang, J.; Jayaseelan, K.V.; O’Donovan, C. MetaboLights: A resource evolving in response to the needs of its scientific community. Nucleic Acids Res. 2020, 48, D440-D444. [CrossRef]

172. Furness, L.M. Bridging the gap: The need for genomic and clinical -omics data integration and standardization in overcoming the bottleneck of variant interpretation. Expert Rev. Precis. Med. Drug Dev. 2017, 2, 79-89. [CrossRef]

173. Borrell, S.; Trauner, A.; Brites, D.; Rigouts, L.; Loiseau, C.; Coscolla, M.; Niemann, S.; De Jong, B.; Yeboah-Manu, D.; Kato-Maeda, M.; et al. Reference set of Mycobacterium tuberculosis clinical strains: A tool for research and product development. PLoS ONE 2019, 14, e0214088. [CrossRef] [PubMed] 